American Journal of Environmental Sciences 4 (5): 420-438, 2008

ISSN 1553-345X

(C) 2008 Science Publications

\title{
Using a Simulation Tool to Model the Ground Level Concentrations of Green House Gases Emitted by Flaring in Petroleum Production in Kuwait Oilfields
}

\author{
${ }^{1}$ Khaireyah Kh. AL-Hamad, ${ }^{1}$ V. Nassehi and ${ }^{2}$ A.R. Khan \\ ${ }^{1}$ Department of Chemical Engineering, \\ Loughborough University, Leicestershire, LE11 3TU, UK \\ ${ }^{2}$ Coastal and Air Pollution Division, Kuwait Institute for Scientific Research \\ P.O. Box 24885, Safat 13109, Kuwait
}

\begin{abstract}
Air pollution and its effects on the ecosystem has been a source of concern for many environmental pollution organizations in the world. In particular climatologists who are not directly involved in petroleum industry sometimes express concerns about the environmental impacts of gas emissions from flaring at well heads. For environmental and resource conservation reasons, flaring should always be minimized as much as practicable and consistent with safety considerations. However, any level of flaring has a local environmental impact, as well as producing emissions which have the potential to contribute to the global warming. In the present research the Industrial Source Complex (ISCST3) Dispersion Model is used to calculate the ground level concentrations of two selected primary pollutants (i.e. methane and non-methane hydrocarbons) emitted due to flaring in all of Kuwait Oilfields. In additional, the performance of the ISCST3 model is assessed, by comparing the model prediction with the observed concentration of methane and non-methane hydrocarbons obtained from the monitoring sites. The described model evaluation is based on the comparison of 50 highest daily measured and predicted concentrations of methane and non-methane hydrocarbons. The overall conclusion of this comparison is that the model predictions are in good agreement with the observed data (accuracy range of 60-95\%) from the monitoring stations maintained by the Kuwait Environmental Public Authority (EPA). A specific important conclusion of this study is that, there is a need for a proper emission inventory strategy for Kuwait Oil Company (KOC) as means of monitoring and minimizing the impact of methane and non-methane hydrocarbons released because of flaring activities.
\end{abstract}

Key words: Kuwait oilfields, ISCST3 model, flare activities, Kuwait-EPA monitoring station

\section{INTRODUCTION}

Kuwait is a major oil exporting country and its economy, growth and prosperity is heavily dependent on oil production. KOC is at the heart of the petroleum production in Kuwait. The oilfields involve various types of industrial operations and activities, such as drilling, production of crude oil, fuel combustion and flaring of gases which all result in gas emission into atmosphere. In practice, all other sources of emissions are small compared with emissions from flaring. Consequently, a wide range of air pollutant emissions is generated on various sites. Such emissions include carbon dioxide, nitrogen and sulfur oxide gases, methane and non-methane hydrocarbons and suspended particulates.

A comprehensive impact assessment study has been previously published ${ }^{[1]}$ which provides an account and estimates of all emissions of primary pollutants associated from flaring activities in the Kuwait Oilfields. This inventory records the annual emissions of air pollutants: $\mathrm{NO}_{\mathrm{X}}, \mathrm{SO}_{2}, \mathrm{CO}, \mathrm{CO}_{2}$, methane and non-methane hydrocarbons. The emissions are generated from various point sources and aggregated to obtain total pollutants load of ambient air. The emissions of pollutants from the flaring associated with all types of operations in the oilfields, Gathering Centers (GC), Booster Stations (BS), tank areas and other oil production related activities.

In the present research the previously published data are used as the necessary input for the ISCST3 model. Obviously methane and non-methane hydrocarbons are not the only green house gasses which result from flaring activities.

However these gases provide a typical sample which can be used as an input for the ISCST3 model to

Corresponding Author: Khaireyah Kh. AL-Hamad, Department of Chemical Engineering, Loughborough University, Leicestershire, LE11 3TU, UK 
investigate of the effects of gases emitted from flaring in all of Kuwait Oilfields.

\section{EPA MONITORING STATIONS IN THE STATE OF KUWAIT}

Kuwait EPA has established a number of fixed monitoring stations to collect air quality data in the urban areas. These stations continuously measure the levels of pollutants such as $\mathrm{SO}_{2}, \mathrm{NO}_{2}, \mathrm{CO}, \mathrm{NO}, \mathrm{CO}_{2}$, $\mathrm{H}_{2} \mathrm{~S}, \mathrm{O}_{3}$ and TSP (total suspended particles) in the air. In additional, the hourly air pollutants concentrations are measured continuously by fixed ambient air stations located over the State of Kuwait.

It is important to note that, in general, all of the monitoring stations are considered as urban stations distributed within the residential areas except for Um Al-Aish station, which is located in the northern part of the country far away from the residential areas. Fig. 1 shows the area map and the locations of Kuwait-EPA air quality monitoring sites. These monitoring stations are equipped with an automatic analyzer and meteorological sensors.

In order to assess the air quality in Kuwait, measurement of the concentrations of pollutants are collected from the Kuwait-EPA air quality-monitoring network. These concentration values of methane and non-methane hydrocarbons are analyzed and compared with the specified limits and guidelines published by the EPA and the model predictions for the ground level concentrations of methane and non-methane hydrocarbons from flaring in Kuwait Oilfields.

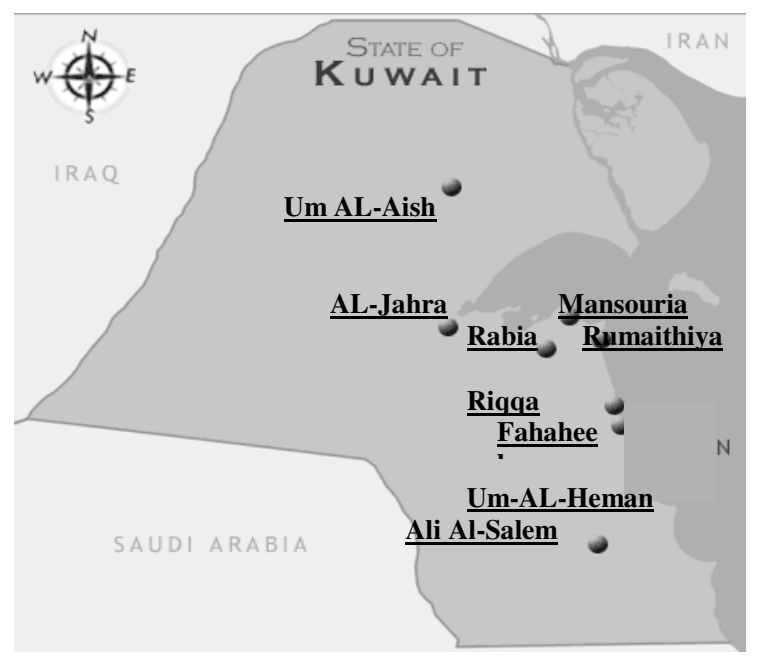

Fig. 1: Location of the air quality monitoring network in the state of Kuwait.

\section{DESCRIPTION OF THE GEOGRAPHY AND METEOROLOGICAL CONDITIONS IN THE STATE OF KUWAIT}

Geography of Kuwait: Kuwait has a small area of about $17,818 \mathrm{~km}^{2}$. At its most distant points, it is about $200 \mathrm{~km}$ north to south and $170 \mathrm{~km}$ east to west.

Kuwait is shaped roughly like a triangle, surrounded by land on its northern, western and southern sides and sea on its eastern side, with $195 \mathrm{~km}$ of coastlines. The bulk of the Kuwaiti populations live in the coastal capital city of Kuwait. Smaller populations inhabit the nearby city of Al-Jahrah. Kuwait's land is mostly flat and arid with little or no ground water.

Meteorological conditions in Kuwait: Kuwait has a typical desert climate, hot and dry most of the time. Rainfall varies from seventy five to $150 \mathrm{~mm}$ a year across the country, however, rainfall ranging from twenty-five $\mathrm{mm}$ a year to as much as $325 \mathrm{~mm}$ have also been recorded.

In summer, average daily temperatures range from $42-46^{\circ} \mathrm{C}$, the highest recorded temperature has been $51.5^{\circ} \mathrm{C}$. The summers are relentlessly long, punctuated mainly by dramatic dust storms in June and July when northwesterly winds cover the cities in sand. In late summer, which is more humid, there are occasional sharp, brief thunderstorms.

Starting from November colder winter weather sets in temperatures dropping as low as $0^{\circ} \mathrm{C}$ at nights; daytime temperature remains in the $15-20^{\circ} \mathrm{C}$ range. Frost rarely occurs; rain is more common and falls mostly in the winter and spring.

Winters (November through February) are cool with some precipitation and average temperatures around $13^{\circ} \mathrm{C}\left(56^{\circ} \mathrm{F}\right)$ with extremes from $2-27^{\circ} \mathrm{C}$. The spring season (March) is warm and pleasant with occasional thunderstorms. Surface coastal water temperatures range from $15^{\circ} \mathrm{C}\left(59^{\circ} \mathrm{F}\right)$ in February to $35^{\circ} \mathrm{C}\left(95^{\circ} \mathrm{F}\right)$ in August. The winter months are often pleasant, featuring some of the region's coolest weather, with daytime temperatures hovering around $18^{\circ} \mathrm{C}$ $\left(64^{\circ} \mathrm{F}\right)$ and nights being genuinely chilly. Sandstorms occur throughout the year but are particularly common in spring.

State of Kuwait meteorological and data analysis for the year 2006: The meteorological conditions play a major role in the dispersion of the pollutions over the State of Kuwait. Therefore, the aim here is to report on 
real meteorological conditions measured and recorded so that a clear picture can be drown about the climate in the state of Kuwait and its affect on the air pollution.

In order to use the meteorological data as input in the ISCST3 model a pre-processing program based on the US EPA. PCRAMMET is utilized to convert the Kuwait data into a suitable format.

A one year hourly record of the surface and upper air meteorological data for year 2006 obtained from the Kuwait International Airport (KIA) weather station is used in the present study for simulation of the dispersion of methane and non-methane hydrocarbons emitted from flaring in all Kuwait Oilfields areas (NK, SEK, WK).

One of the main meteorological factors that can affect the behavior of the pollutants trends during a day is the mixing height and depth of the mixing layer. US$\mathrm{EPA}^{[2,3,4]}$ stated that the estimation of mixing heights from upper air meteorological data is a critical parameter for understanding the formation, dispersion and transfer of ozone and precursors during pollution episodes. The upper air meteorological data were obtained from routine measurements at the KIA weather station for the year 2006. These data were used to calculate the mixing heights (Fig. 2.) and investigate the effects of upper air meteorological data in the diurnal behaviors of ozone and its precursors.

The morning and afternoon mixing height estimates are determined based on the method described by Holzworth ${ }^{[5]}$ and Hanna ${ }^{[6]}$. Mixing height is estimated by plotting maximum surface temperature and drawing a line parallel to the dry adiabatic lapse rate from the point of maximum surface temperature to point at which the line intersects the ambient lapse rate early morning as shown in Fig. 2.

The prevailing wind direction in Kuwait is along the north westerly quadrant throughout the year, but it is more so in summer. Figure $3 \mathrm{a}$ and $3 \mathrm{~b}$ show detailed wind rose plots for the year 2006 and the main two seasons in Kuwait.

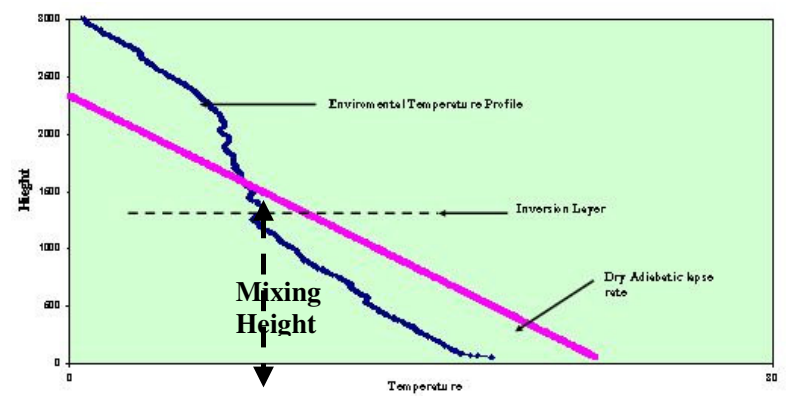

Fig. 2: Upper air temperature profile and formation of the temperature inversion

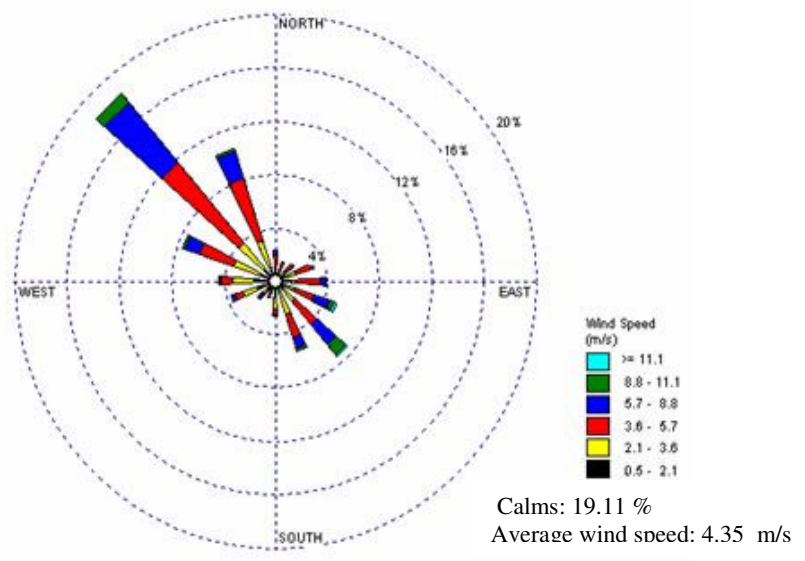

Fig. 3a: Wind rose plot for winter (November-March)

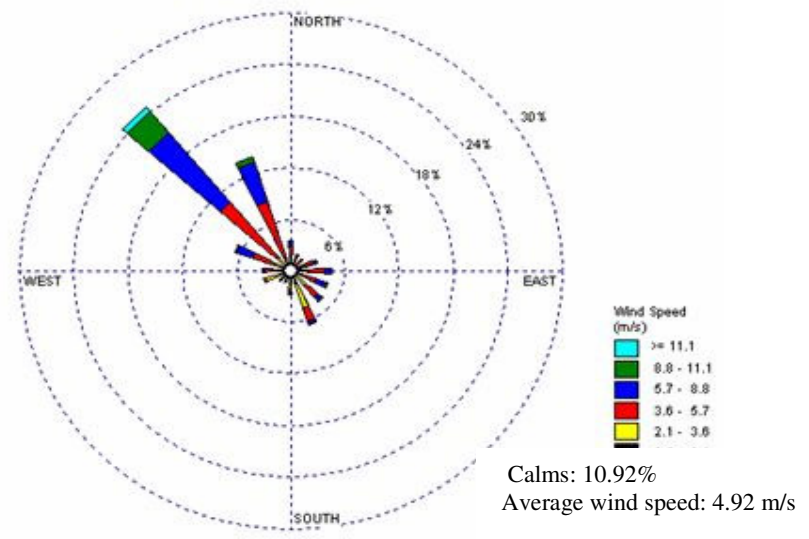

Fig. 3b: Wind rose plot for summer (April-October)

about $14.3 \%$ of the total time and an average wind speed of $4.7 \mathrm{~m} \mathrm{sec}^{-1}$. Figure $3 \mathrm{a}$ shows the wind rose plot for the winter (November-March) where most of the time the prevailing wind direction is from the North West with calm conditions about $19.11 \%$ of the total time and an average wind speed of $4.35 \mathrm{~m} \mathrm{sec}^{-1}$. Figure $3 \mathrm{~b}$ provides the wind rose plot for summer (April-October) and shows that the prevailing wind direction is also from the North West. This indicates that there no marked seasonal variation in the wind direction throughout the year. The prevailing wind direction in summer is more established than winter season with calm wind $10.92 \%$ of the total time and an average wind speed of $4.92 \mathrm{~m} \mathrm{sec}^{-1}$. Moreover, there is no significant diurnal variation in the prevailing wind direction during the day and night times. This tends to minimize the effects of any land or sea breeze in the 
dispersion of the pollutants in the urban areas of Kuwait.

The most important meteorological element that can control the level of the atmospheric pollution is the wind. The wind in the state of Kuwait results from the influence of the pressure systems, which dominate the area during each season.

In Fig. 4, the frequency distribution of the winds is illustrated. There are about $32.2 \%$ of wind speed record is in between $3.6-5.7 \mathrm{~m} \mathrm{sec}^{-1}$ and about $17.5 \%$ of wind speed record in between 2.1-3.6 $\mathrm{m} \mathrm{s}^{-1}$. As shows in detailed wind rose plots (Fig. 3, a and b), the main prevailing wind direction in NW is more frequent than other directions (i.e., N, NNW and W). In addition, it can be noted that the North West wind direction coincides with high wind speeds than other directions.

The effect of the wind speed is a very important parameter in the dispersion of pollutants as the relationships between the wind speed and the concentration of pollutants downwind of a source is of inversely proportional. This means that when the wind speed reaches its highest level it actually helps in reducing the concentration of any air pollution, thus reducing its hazardous effects on the residential area. On the other hand, slow winds allow for high concentration of pollutants moving slowly over residential areas.

Table 1 shows the Mean Monthly Wind Speed (MMWS) and the Mean Monthly Ambient Temperature (MMAT) for 2006. These mean monthly meteorological data were computed from the hourly records during each day of 2006. The annual mean wind speed in 2006 is low being only $4.04 \mathrm{~m} \mathrm{sec}^{-1}$, while MMWS reaches its highest in June $\left(5.23 \mathrm{~m} \mathrm{sec}^{-1}\right)$ and in July $\left(6.07 \mathrm{~m} \mathrm{sec}^{-1}\right)$ and its lowest in January

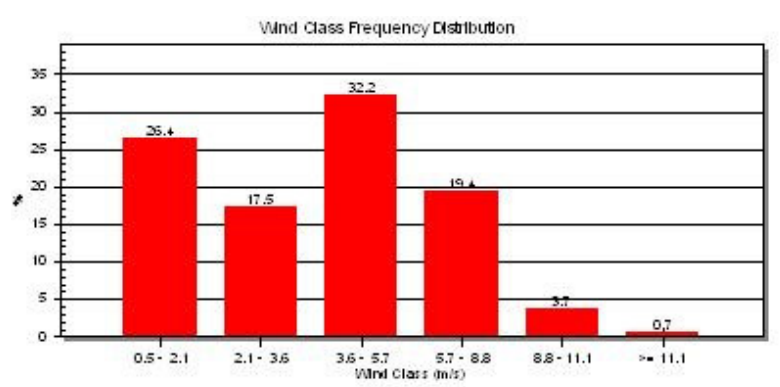

Fig. 4: Frequency Distribution of the Wind Speed Class during the year 2006
Table 1: Mean Monthly Meteorological Conditions for year 2006

\begin{tabular}{lcc}
\hline Month & $\begin{array}{l}\text { Mean wind speed } \\
\left(\mathrm{m} \mathrm{sec}^{-1}\right)\end{array}$ & $\begin{array}{l}\text { Mean ambient } \\
\text { temperature }\left({ }^{\circ} \mathrm{C}\right)\end{array}$ \\
\hline January & 3.18 & 13.50 \\
February & 3.73 & 15.94 \\
March & 4.10 & 21.17 \\
April & 4.01 & 26.30 \\
May & 4.27 & 34.25 \\
June & 5.23 & 38.52 \\
July & 6.07 & 40.04 \\
August & 3.75 & 39.34 \\
September & 3.66 & 34.41 \\
October & 3.76 & 30.18 \\
November & 3.43 & 19.58 \\
December & 3.33 & 11.61 \\
Average & 4.04 & 27.07 \\
\hline
\end{tabular}

$\left(3.18 \mathrm{~m} \mathrm{sec}^{-1}\right)$. The annual mean temperature was $27.07^{\circ} \mathrm{C}$ where the lowest MMAT recorded during the year was $11.61^{\circ} \mathrm{C}$ in December and the highest MMAT was $40.04^{\circ} \mathrm{C}$ in July. This variation of temperature and wind speeds may have serious consequences on determining the level of air pollution and hence the air quality, especially in residential areas closes to $\mathrm{KOC}$ Oilfields.

Figure 5 shows the MMAT, maximum and minimum temperatures recorded for each month. The maximum temperature in summer ranges from $40-51^{\circ} \mathrm{C}$.

Table 2 shows the frequency distribution count for the wind direction under a specify winds speed class in 2006. The frequency of the calm winds was $14.3 \%$ of the 8736 hourly record data. In meteorology, the wind direction considered as the direction from which the wind is bellows therefore, a North West (NW) wind will move pollutants to the South East (SE) of the source. Hence, this consideration was taken into account in a construction of Table 1 and the wind rose plot shown in Fig. 3 to make the analysis of the wind

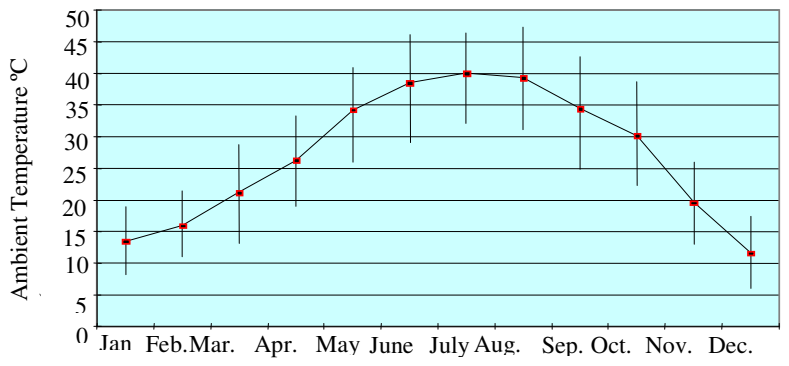

Fig. 5: The mean monthly, maximum and minimum record of ambient air temperature for year 2006 
Table 2: Frequency distribution counts for the wind direction in year 2006

\begin{tabular}{|c|c|c|c|c|c|c|c|}
\hline \multirow{2}{*}{$\begin{array}{l}\text { Wind } \\
\text { direction }\end{array}$} & \multicolumn{7}{|c|}{ Wind speed class in $\left(\mathrm{m} \mathrm{sec}^{-1}\right)$} \\
\hline & $0.5-2.1$ & $2.1-3.6$ & $3.6-5.7$ & $5.7-8.8$ & 8.8-11.1 & $>=11.1$ & 1 Total \\
\hline$\overline{\mathrm{N}}$ & 33 & 43 & 144 & 47 & 0 & 0 & 267 \\
\hline NNE & 21 & 54 & 74 & 10 & 0 & 0 & 159 \\
\hline $\mathrm{NE}$ & 30 & 40 & 85 & 6 & 1 & 0 & 162 \\
\hline ENE & 32 & 61 & 154 & 28 & 0 & 0 & 275 \\
\hline E & 35 & 82 & 204 & 60 & 1 & 0 & 382 \\
\hline ENE & 34 & 79 & 156 & 106 & 25 & 5 & 405 \\
\hline SE & 77 & 122 & 161 & 106 & 42 & 6 & 514 \\
\hline SSE & 126 & 205 & 150 & 48 & 8 & 2 & 539 \\
\hline $\mathrm{S}$ & 97 & 95 & 35 & 11 & 2 & 0 & 240 \\
\hline SSW & 59 & 38 & 21 & 12 & 1 & 0 & 131 \\
\hline SW & 69 & 36 & 31 & 23 & 2 & 0 & 161 \\
\hline WSW & 132 & 112 & 42 & 9 & 1 & 0 & 296 \\
\hline W & 114 & 109 & 77 & 20 & 0 & 3 & 323 \\
\hline WNW & 76 & 132 & 247 & 136 & 17 & 2 & 610 \\
\hline NW & 78 & 174 & 697 & 753 & 193 & 38 & 1933 \\
\hline NNW & 47 & 144 & 536 & 324 & 33 & 6 & 1090 \\
\hline Total & 1060 & 1526 & 2814 & 1699 & 326 & 62 & 7487 \\
\hline
\end{tabular}

data more consistencies with the modeling results. However, it is very important to note that the ISCST3 model considers the wind direction as the direction towards which the wind is blowing.

\section{MATHEMATICAL MODEL}

Industrial Source Complex (ISCST3) dispersion model modified by the US EPA in 1999 is used in the present study. The ISCST3 algorithm is based on a Gaussian plume dispersion model (i.e., it solves the steady-state Gaussian plume equation) and calculates short-term pollutant concentrations from multiple point sources at a specified receptor grid on a level or gently sloping terrain. The ISCST3 model includes a wide range of options for modeling air quality impacts of pollution sources, making it a popular choice for the modeling community is a variety of applications.

Since the ISCST3 model is specially designed to support the US EPA's regulatory model programs ${ }^{[3,4]}$, the regulatory modeling options, as specified in the revised guidelines for air quality models (USA-EPA, 1999), are the default mode of operation for the models. These options include the use of stack-tip downwash, buoyancy-induced dispersion, final plume rise, a routine for processing averages when calm winds prevail, default values for wind profile exponents and for the vertical potential temperature gradients and the use of upper bound estimates for super squat buildings having an influence on the lateral dispersion of the plume.
The model is capable of handling multiple sources, including point, volume, area and open pit source types. Line sources may also be modeled as a string of volume sources or as elongated area sources. Several source groups may be specified in a single run, with the source contributions combined for each group.

The ISCST3 model implementation requires three main inputs data as follows:

Source information: The source parameters required for the ISCST3 numerical model are pollutant emission rate $(\mathrm{g} \mathrm{sec}-1)$, location coordinates (UTM), source height $(\mathrm{m})$, exit inner diameter $(\mathrm{m})$, exit gas speed $\left(\mathrm{m} \mathrm{sec}{ }^{-1}\right)$ and exit gas temperature $\left({ }^{\circ} \mathrm{C}\right)$. All the required information on the location coordinates, the emission rates and heights of stacks, diameters, speeds and temperatures of the gas flow at the exits of the stacks were collected from flaring activities from Kuwait oil field as stated in previous published.

Receptor information: The ISCST3 model have considerable flexibility in the specification of receptor locations, has the capability of specifying multiple receptor networks in a single run and may also mix Cartesian grid receptor networks and polar grid receptor networks in the same run.

Two different kinds of Cartesian coordinate receptors were used as an input to the ISCST3 model, these are:

- The uniform grid system of 441 receptors which cover approximately 55 by $53 \mathrm{~km}$. The grid base elements is a square with side length of $1 \mathrm{~km}$. Figure 6 describes one plot figure of the grid under study

- Discrete Receptors points corresponding to the location of the major pollution centers and the existing monitoring stations in the State of Kuwait. This means that concentrations in each point in the grid, which is $1 \mathrm{~km}$, will be estimated in addition to the discrete point of the existing monitoring stations. The matrix of concentrations can be plotted as a contour map for the selected meteorological data file

Indeed, the uniform grid receptors are not need for the model evaluation, neither for investigation of the efficiency of the monitoring sites, but it is a way to have a general view of the pollutants dispersion over the study area. 
These receptors are selected based on actual sites in UTM location coordinate of Kuwait map as shown in Fig. 6.

Meteorological information: The meteorological data required are anemometer height $(\mathrm{m})$ wind speed (v), wind direction (degree) clockwise from the north, air temperature, total and opaque cloud cover (\%), stability class at the hour of measurement (dimensionless) and mixing height $(\mathrm{m})$. The anemometer height, wind speed, wind direction, air temperature and cloud cover are usually obtained from direct measurements.

The hourly stability class and the hourly mixing height are estimated using PCRAMMET. PCRAMMET is a meteorological pre-processor for preparing National Weather Service (NWS) data for use in the ISCST3 US-EPA. The routine measurements of the surface and upper air meteorological data obtained from KIA for the year 2006 is used to run the PCRAMMET to generate an hourly ASCII input meteorological file containing the meteorological information parameters needed for the running of the ISCST3 model.

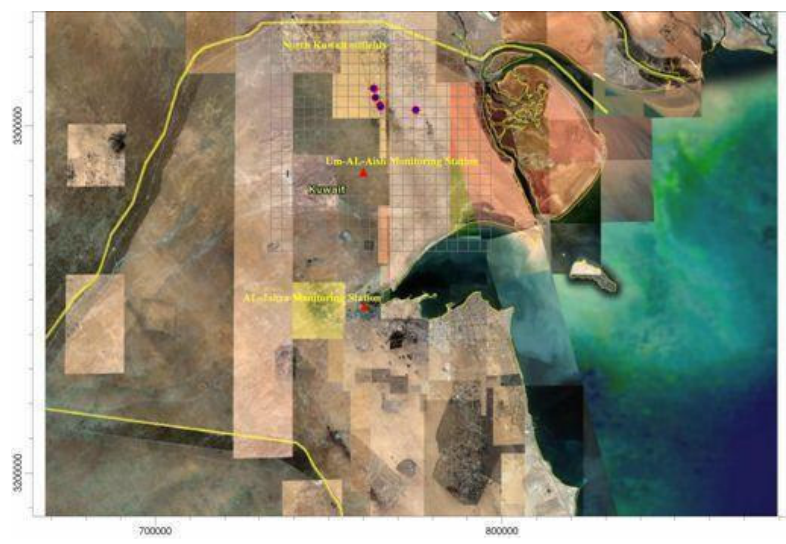

Fig. 6: The one grid area under study

The anemometer height of this station is $10 \mathrm{~m}$. The average hourly meteorological data for 2006 were assumed to be valid for the periods investigated

The stability class was defined on the basis of Pasquill categories, which are mainly a function of the hour of measurement, wind speed and sky cover (i.e., the amount of clouds). Based on temperature profile measurements, the mixing height was estimated by the model.

\section{DESCRIPTION OF THE STUDY AREA}

The subject area of the present study covers all of the Kuwait's oil producing zones which are located in three selections in the state of Kuwait (Fig. 7). Figure 7 shows the Kuwait map with the location of the three oil producing areas (SEK, WK and NK) and the location of the residential areas.

The distance between the farthest northeast and southeast points of the state boundaries is about 200 $\mathrm{Km}$ and from farthest east to west is about $170 \mathrm{Km}$. Therefore, the total length of the border line is about $685 \mathrm{Km}$. To cover all of this area, modeling is divided into three individual tasks to calculate the ground level concentrations of methane and non-methane hydrocarbons. The modeling tasks are:

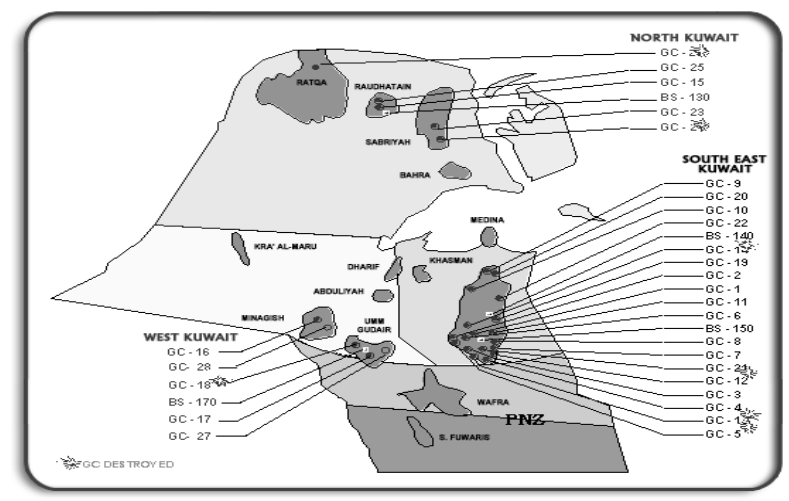

Fig. 7: Major oilfields and gathering Center (GC) in the state of kuwait

SouthEast Kuwait (SEK) area: Calculated greater Burgan area located in SEK, which has 14 gathering centers.

West Kuwait (WK) area: Calculated Minagish and Umm Gudair fields located in WK have 4 GCs and two BS's.

North Kuwait (NK) area: Calculated Ratqa, Raudatin and Sabiriyah which located in NK have 3 GCs and one BS.

\section{RESULTS AND DISCUSSIONS}

ISCST3 model was set up to simulate the ground level concentrations of methane and non-methane hydrocarbons emitted from flaring activities in $\mathrm{KOC}$ at all points covered by the receptors information. Modeling was then carried out by summing the steady state concentration contributions from each source at each receptor point in the study area. The calculations were done based on the model input parameters as described in the previous sections. The simulated results of the emission scenarios using the ISCST3 are 
on an hourly basis for the predicted concentrations of methane and non-methane hydrocarbons.

The hourly, daily and annual average maximum ground level concentrations of methane and nonmethane hydrocarbons were predicted and output results were compared with Kuwait Ambient Air Quality Standards (KAAQS) at all of the grid point receptors under the study area (443 receptors) as shown in Fig. 6. The maximum hourly, daily and annual Allowable levels of pollutants specified by KAAQS are shown in Table 3. The maximum hourly level as indicated by KAAQS can be exceeded only once a month during a year in the same location. However, the daily and annually allowable limits are not to be exceeded.

North Kuwait oilfield area results

Methane emission: Table 4a-c show the modeling results for the 50 highest hourly, 50 highest daily and the 50 highest annual maximum ground level

Table 3: Kuwait EPA standards for ambient air

\begin{tabular}{|c|c|c|c|c|c|}
\hline \multirow[b]{2}{*}{ Pollutants } & \multirow[b]{2}{*}{ Units } & \multicolumn{3}{|l|}{ Standards } & \multirow[b]{2}{*}{ Hourly } \\
\hline & & Annual & $24 \mathrm{~h}$ & $8 \mathrm{~h}$ & \\
\hline$\overline{\mathrm{NO}_{2}}$ & $\mathrm{ppb}$ & $30\left(67 \mu \mathrm{g} \mathrm{m}^{-3}\right)$ & $50\left(112 \mu \mathrm{g} \mathrm{m}^{-3}\right)$ & & $100\left(225 \mu \mathrm{gm}^{-3}\right)$ \\
\hline $\mathrm{SO}_{2}$ & ppb & $30\left(80 \mu \mathrm{g} \mathrm{m}^{-3}\right)$ & $60\left(157 \mu \mathrm{g} \mathrm{m}^{-3}\right)$ & & $170\left(444 \mu \mathrm{gm}^{-3}\right)$ \\
\hline $\mathrm{H}_{2} \mathrm{~S}$ & $\mathrm{ppb}$ & $6\left(8 \mu \mathrm{g} \mathrm{m}^{-3}\right)$ & $30\left(40 \mu \mathrm{g} \mathrm{m}^{-3}\right)$ & & $140\left(200 \mu \mathrm{gm}^{-3}\right)$ \\
\hline $\mathrm{CO}$ & ppm & & $8\left(9 \mathrm{mg} \mathrm{m}^{-3}\right)$ & $10(11.5)$ & $30\left(34 \mathrm{mg} \mathrm{m}^{-3}\right)$ \\
\hline $\mathrm{O}_{3}$ & $\mathrm{ppb}$ & & & $60(120)$ & $80\left(157 \mu \mathrm{gm}^{-3}\right)$ \\
\hline Non-methane & ppm & & & & 0.24 ( $3 \mathrm{~h}$ mean $)$ \\
\hline Hydrocarbons & & & & & $6: 00-9: 00 \mathrm{am}$ \\
\hline $\mathrm{PM}_{10}$ & $\mu \mathrm{g} \mathrm{m}^{-3}$ & 90 & 350 & & \\
\hline Mercury & $\mu \mathrm{g} \mathrm{m}^{-3}$ & 1 & & & \\
\hline
\end{tabular}

Table 4a: ISCST3 output data modeling results for the 50 highest hourly average concentrations of methane

\begin{tabular}{|c|c|c|c|c|c|c|c|c|c|}
\hline \multirow[b]{2}{*}{ Rank } & \multirow[b]{2}{*}{$\begin{array}{l}\text { CONC } \\
\left(\mu \mathrm{g} \mathrm{m}^{-1}\right)\end{array}$} & \multirow[b]{2}{*}{ (YYMMDDHH) } & \multicolumn{2}{|c|}{$\begin{array}{l}\text { Location Coordinate } \\
\text { in UTM }(\mathrm{m})\end{array}$} & \multirow[b]{2}{*}{ Rank } & \multirow[b]{2}{*}{$\begin{array}{l}\text { CONC. } \\
\left(\mu \mathrm{g} \mathrm{m}^{-1}\right)\end{array}$} & \multirow[b]{2}{*}{ (YYMMDDHH) } & \multicolumn{2}{|c|}{$\begin{array}{l}\text { Location Coordinate in } \\
\text { in UTM }(\mathrm{m})\end{array}$} \\
\hline & & & $\mathrm{X}$ & $\mathrm{Y}$ & & & & $\mathrm{X}$ & $\mathrm{Y}$ \\
\hline 1 & 2761.5000 & 6011902 & 774643.69 & 3305361.25 & 26 & 1159.27 & 6041903 & 774643.69 & 3305361.25 \\
\hline 2 & 2564.3000 & 6120501 & 774643.69 & 3305361.25 & 27 & 986.26 & 6022701 & 774643.69 & 3305361.25 \\
\hline 3 & 2464.0000 & 6040303 & 774643.69 & 3305361.25 & 28 & 970.53 & 6041606 & 774643.69 & 3305361.25 \\
\hline 4 & 2464.0000 & 6040601 & 774643.69 & 3305361.25 & 29 & 954.02 & 6051002 & 774643.69 & 3305361.25 \\
\hline 5 & 2071.1000 & 6090701 & 774643.69 & 3305361.25 & 30 & 951.64 & 6090524 & 761955.63 & 3308548.75 \\
\hline 6 & 1898.5000 & 6042623 & 774643.69 & 3305361.25 & 31 & 934.89 & 6041006 & 774643.69 & 3305361.25 \\
\hline 7 & 1794.9000 & 6122607 & 774643.69 & 3305361.25 & 32 & 915.70 & 6022407 & 765127.63 & 3308548.75 \\
\hline 8 & 1775.2000 & 6111822 & 774643.69 & 3305361.25 & 33 & 892.15 & 6040422 & 761955.63 & 3308548.75 \\
\hline 9 & 1725.9000 & 6021420 & 774643.69 & 3305361.25 & 34 & 887.63 & 6060323 & 774643.69 & 3305361.25 \\
\hline 10 & 1635.5000 & 6060705 & 774643.69 & 3305361.25 & 35 & 886.39 & 6060101 & 765127.63 & 3308548.75 \\
\hline 11 & 1612.8000 & 6010606 & 774643.69 & 3305361.25 & 36 & 882.96 & 6042104 & 765127.63 & 3308548.75 \\
\hline 12 & 1612.8000 & 6011904 & 774643.69 & 3305361.25 & 37 & 882.96 & 6042221 & 765127.63 & 3308548.75 \\
\hline 13 & 1610.9000 & 6090224 & 774643.69 & 3305361.25 & 38 & 855.47 & 6052805 & 774643.69 & 3305361.25 \\
\hline 14 & 1575.3000 & 6120608 & 774643.69 & 3305361.25 & 39 & 843.13 & 6112919 & 774643.69 & 3305361.25 \\
\hline 15 & 1557.2000 & 6091105 & 765127.63 & 3308548.75 & 40 & 824.89 & 6062223 & 774643.69 & 3305361.25 \\
\hline 16 & 1518.8000 & 6042124 & 774643.69 & 3305361.25 & 41 & 805.43 & 6052505 & 774643.69 & 3305361.25 \\
\hline 17 & 1518.8000 & 6042902 & 774643.69 & 3305361.25 & 42 & 793.26 & 6090219 & 774643.69 & 3305361.25 \\
\hline 18 & 1475.4000 & 6090801 & 774643.69 & 3305361.25 & 43 & 789.01 & 6100401 & 774643.69 & 3305361.25 \\
\hline 19 & 1344.3000 & 6040504 & 774643.69 & 3305361.25 & 44 & 784.87 & 6052604 & 765127.63 & 3308548.75 \\
\hline 20 & 1265.7000 & 6042206 & 774643.69 & 3305361.25 & 45 & 778.58 & 6071902 & 765127.63 & 3308548.75 \\
\hline 21 & 1264.7000 & 6060502 & 774643.69 & 3305361.25 & 46 & 772.87 & 6042905 & 774643.69 & 3305361.25 \\
\hline 22 & 1264.7000 & 6110503 & 774643.69 & 3305361.25 & 47 & 743.68 & 6060524 & 774643.69 & 3305361.25 \\
\hline 23 & 1197.7000 & 6010220 & 761955.63 & 3308548.75 & 48 & 716.10 & 6042207 & 774643.69 & 3305361.25 \\
\hline 24 & 1191.5000 & 6120503 & 774643.69 & 3305361.25 & 49 & 706.91 & 6022424 & 765127.63 & 3308548.75 \\
\hline 25 & 1167.8713 & 6091922 & 765127.63 & 3308548.75 & 50 & 702.61 & 6022720 & 774643.69 & 3305361.25 \\
\hline
\end{tabular}


Am. J. Environ. Sci., 4 (5): 420-438, 2008

Table 4b: ISCST3 output data modeling results for the 50 highest daily average concentrations of methane

\begin{tabular}{|c|c|c|c|c|c|c|c|c|c|}
\hline \multirow[b]{2}{*}{ Rank } & \multirow{2}{*}{$\begin{array}{l}\text { CONC. } \\
\left(\mu \mathrm{g} \mathrm{m}^{-1}\right)\end{array}$} & \multirow[b]{2}{*}{ (YYMMDDHH) } & \multicolumn{2}{|c|}{$\begin{array}{l}\text { Location Coordinate } \\
\text { in UTM }(\mathrm{m})\end{array}$} & \multirow[b]{2}{*}{ Rank } & \multirow[b]{2}{*}{$\begin{array}{l}\text { CONC. } \\
\left(\mu \mathrm{g} \mathrm{m}^{-1}\right)\end{array}$} & \multirow[b]{2}{*}{ (YYMMDDHH) } & \multicolumn{2}{|c|}{$\begin{array}{l}\text { Location Coordinate in } \\
\text { in UTM }(\mathrm{m})\end{array}$} \\
\hline & & & $\mathrm{X}$ & $\mathrm{Y}$ & & & & $\mathrm{X}$ & $\mathrm{Y}$ \\
\hline 1 & 248.49 & 6011924 & 774643.69 & 3305361.25 & 26 & 78.346 & 6090824 & 774643.69 & 3305361.25 \\
\hline 2 & 208.66 & 6120524 & 774643.69 & 3305361.25 & 27 & 77.105 & 6100824 & 774643.69 & 3305361.25 \\
\hline 3 & 159.85 & 6042924 & 774643.69 & 3305361.25 & 28 & 75.908 & 6091124 & 765127.63 & 3308548.75 \\
\hline 4 & 156.94 & 6040624 & 774643.69 & 3305361.25 & 29 & 72.511 & 6040524 & 774643.69 & 3305361.25 \\
\hline 5 & 136.89 & 6040324 & 774643.69 & 3305361.25 & 30 & 68.994 & 6091924 & 765127.63 & 3308548.75 \\
\hline 6 & 134.01 & 6090224 & 774643.69 & 3305361.25 & 31 & 66.552 & 6010224 & 761955.63 & 3308548.75 \\
\hline 7 & 127.98 & 6022724 & 774643.69 & 3305361.25 & 32 & 64.040 & 6010824 & 774643.69 & 3305361.25 \\
\hline 8 & 120.64 & 6060524 & 774643.69 & 3305361.25 & 33 & 62.837 & 6113024 & 774643.69 & 3305361.25 \\
\hline 9 & 117.64 & 6090724 & 774643.69 & 3305361.25 & 34 & 61.357 & 6120924 & 765127.63 & 3308548.75 \\
\hline 10 & 115.44 & 6042224 & 774643.69 & 3305361.25 & 35 & 61.036 & 6041624 & 774643.69 & 3305361.25 \\
\hline 11 & 112.14 & 6122624 & 774643.69 & 3305361.25 & 36 & 60.766 & 6060124 & 765127.63 & 3308548.75 \\
\hline 12 & 111.75 & 6022424 & 765127.63 & 3308548.75 & 37 & 59.883 & 6012424 & 774643.69 & 3305361.25 \\
\hline 13 & 108.44 & 6012924 & 765127.63 & 3308548.75 & 38 & 59.298 & 6022824 & 774643.69 & 3305361.25 \\
\hline 14 & 107.91 & 6100424 & 774643.69 & 3305361.25 & 39 & 58.420 & 6012024 & 774643.69 & 3305361.25 \\
\hline 15 & 104.91 & 6010624 & 774643.69 & 3305361.25 & 40 & 57.395 & 6101024 & 774643.69 & 3305361.25 \\
\hline 16 & 100.32 & 6080824 & 774643.69 & 3305361.25 & 41 & 56.456 & 6092424 & 774643.69 & 3305361.25 \\
\hline 17 & 99.11 & 6111824 & 774643.69 & 3305361.25 & 42 & 56.160 & 6122724 & 774643.69 & 3305361.25 \\
\hline 18 & 97.57 & 6042124 & 774643.69 & 3305361.25 & 43 & 55.527 & 6012324 & 765127.63 & 3308548.75 \\
\hline 19 & 96.88 & 6110524 & 774643.69 & 3305361.25 & 44 & 55.392 & 6102124 & 774643.69 & 3305361.25 \\
\hline 20 & 95.36 & 6042624 & 774643.69 & 3305361.25 & 45 & 52.766 & 6041924 & 774643.69 & 3305361.25 \\
\hline 21 & 88.78 & 6021424 & 774643.69 & 3305361.25 & 46 & 52.696 & 6041024 & 774643.69 & 3305361.25 \\
\hline 22 & 87.53 & 6120624 & 774643.69 & 3305361.25 & 47 & 52.469 & 6041524 & 774643.69 & 3305361.25 \\
\hline 23 & 83.76 & 6060724 & 774643.69 & 3305361.25 & 48 & 51.177 & 6100124 & 774643.69 & 3305361.25 \\
\hline 24 & 82.24 & 6041124 & 774643.69 & 3305361.25 & 49 & 50.572 & 6112024 & 774643.69 & 3305361.25 \\
\hline 25 & 78.83 & 6062224 & 774643.69 & 3305361.25 & 50 & 50.545 & 6101924 & 774643.69 & 3305361.25 \\
\hline
\end{tabular}

concentrations of methane, respectively calculated at the uniform grid receptors described previously. Isopleths plots (contours) were generated, as shown in Fig. 8a-c. These present the maximum hourly, daily and annual ground level concentration of methane in $\mu \mathrm{g} \mathrm{m}^{-3}$ calculated at the specified uniform grid receptors.

The data presented in Table 4a-c and Fig. 8a-c reveal that predicted ground level concentrations of methane for the specified time exceeds the KAAQS ambient air quality standard over the study area.

As shown in Table $4 \mathrm{a}$ the predicted maximum hourly average ground level concentration of methane in the study areas exceeds KAAQS by as much as $2761.5 \mu \mathrm{g} \mathrm{m}^{-3}$, hour 02:00, 19th January 2006 at the receptor coordinate of $X=774643.69$, $\mathrm{Y}=3305361.25$. As shown in Fig. 8a, this receptor is located nearly $54 \mathrm{~km}$ in the NNW direction from the centre of NK Oilfields and not far from the residential areas.

The predicted maximum daily average ground level concentration of methane in the study areas in Table $4 \mathrm{~b}$ exceeds KAAQS by as much as $248.49 \mu \mathrm{g} \mathrm{m}^{-3}$, hour 24:00, 19th January 2006 at the receptor coordinate of $\mathrm{X}=774643.69$, $\mathrm{Y}=3305361.25$. Inspection of Fig. 8b, this receptor is located nearly $56 \mathrm{~km}$ in the NNW
Table 4c: ISCST3 output data modeling results for the 10th highest annual average concentrations of methane

\begin{tabular}{llll}
\hline & $\begin{array}{l}\text { LONC. } \\
\left(\mu \mathrm{g} \mathrm{m}^{-3}\right)\end{array}$ & $\mathrm{X}$ & $\mathrm{Y}$ \\
Rank & 6.0005 & 774643.69 & 3305361.25 \\
\hline 1ST & 7.8285 & 765127.63 & 3308548.75 \\
2ND & 4.5797 & 761955.63 & 3311736.00 \\
3RD & 3.5772 & 765127.63 & 3305361.25 \\
4TH & 2.7889 & 761955.63 & 3308548.75 \\
5TH & 2.4240 & 768299.69 & 3302173.75 \\
6TH & 2.1309 & 765127.63 & 3311736.00 \\
7TH & 2.0584 & 777815.69 & 3302173.75 \\
8TH & 2.0575 & 768299.69 & 3305361.25 \\
9TH & 1.7195 & 777815.69 & 3305361.25 \\
10TH & & &
\end{tabular}

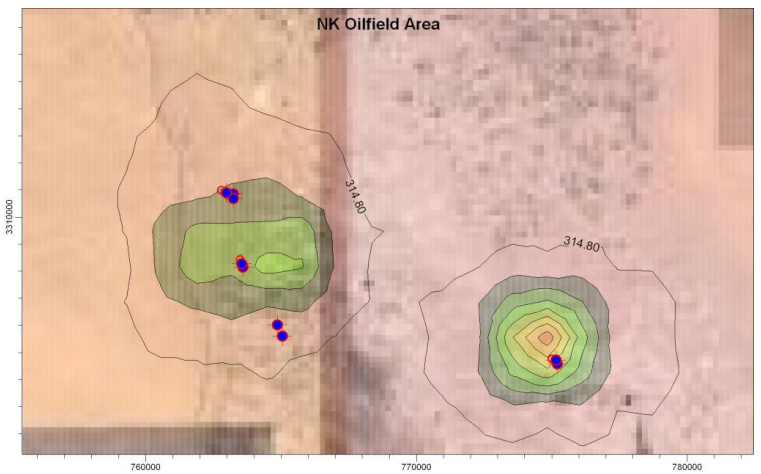

Fig. 8a: Isopleths plot for the maximum hourly average ground level concentrations of methane in $\mu \mathrm{g} \mathrm{m}^{-3}$ 
Am. J. Environ. Sci., 4 (5): 420-438, 2008

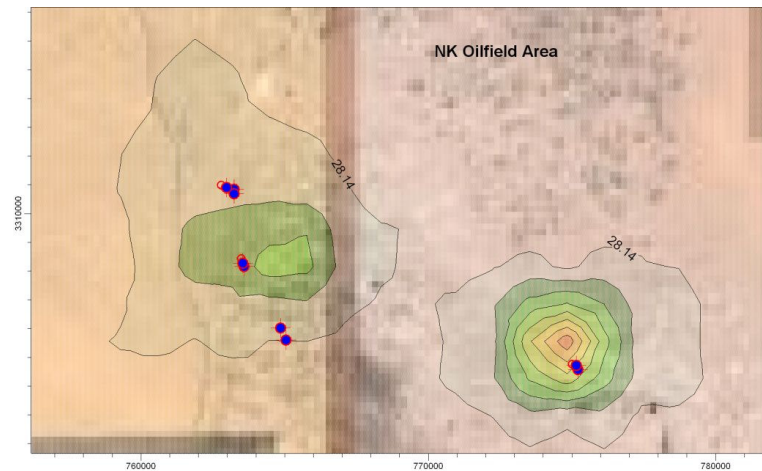

Fig. 8b: Isopleths plot for the maximum hourly average ground level concentrations of methane in $\mu \mathrm{g} \mathrm{m}^{-3}$

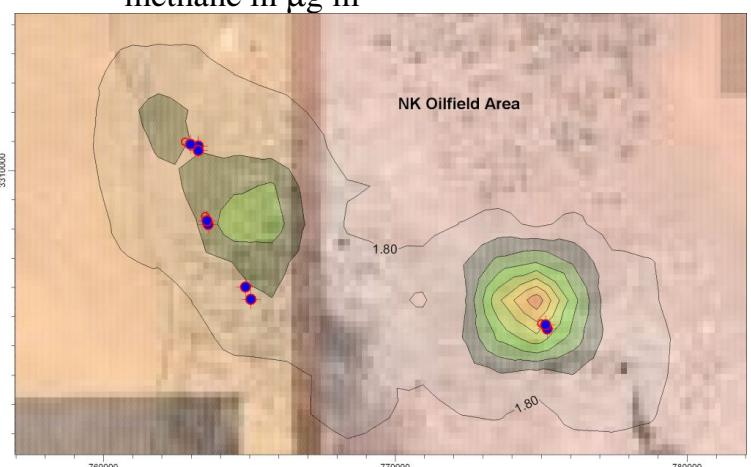

Fig. 8c: Isopleths plot for the maximum annual average ground level concentrations of methane in $\mu \mathrm{g} \mathrm{m}^{-3}$

direction from the centre of NK Oilfields and not far from the residential areas. For the same location,
Table $4 \mathrm{c}$ and Fig. 8c show that the highest annual maximum concentration of methane is $6 \mu \mathrm{g} \mathrm{m}^{-3}$.

Non-methane hydrocarbon emissions: Table 5a-c show the modeling results for the 50 highest hourly, 50 highest daily and the 50 highest annual maximum ground level concentrations of non-methane hydrocarbons, respectively calculated at the uniform grid receptors described previously. Isopleths plots (contours) were generated, as shown in Fig. 9a-c. These present the maximum hourly, daily and annual ground level concentration of non-methane hydrocarbons in $\mu \mathrm{g} \mathrm{m}^{-3}$ calculated at the specified uniform grid receptors.

The described data reveal that predicted ground level concentrations of non-methane for the specified time exceeds the KAAQS ambient air quality standard over the study area.

As shown in Table 5a and Fig. 9a, the predicted maximum hourly average ground level concentration of non-methane hydrocarbons in the study area exceeds KAAQS by as much as $34442.8 \mu \mathrm{g} \mathrm{m} \mathrm{m}^{-3}$, hour 02:00, 19th January 2006 at the a receptor coordinate of $\mathrm{X}=774643.69, \mathrm{Y}=3305361.25$.

The predicted maximum daily average ground level concentration of non-methane hydrocarbons in the study area given in Table $5 \mathrm{~b}$ exceeds KAAQS by as much as $3099.8 \mu \mathrm{g} \mathrm{m}^{-3}$, hour 24:00, 19th January 2006 at the a receptor coordinate of $X=774643.69$,

Table 5a: ISCST3 output data modeling results for the 50 highest hourly average concentrations of non-methane hydrocarbons

\begin{tabular}{|c|c|c|c|c|c|c|c|c|c|}
\hline \multirow[b]{2}{*}{ Rank } & \multirow[b]{2}{*}{$\begin{array}{l}\text { CONC } \\
\left(\mu \mathrm{g} \mathrm{m}^{-1}\right)\end{array}$} & \multirow[b]{2}{*}{ (YYMMDDHH) } & \multicolumn{5}{|c|}{ Location coordinate in UTM (m) } & \multicolumn{2}{|c|}{ Location coordinate in UTM (m) } \\
\hline & & & $X$ & $\mathrm{Y}$ & Rank & $\begin{array}{l}\text { CONC. } \\
\left(\mu \mathrm{g} \mathrm{m}^{-1}\right)\end{array}$ & (YYMMDDHH) & $\mathrm{X}$ & $\mathrm{Y}$ \\
\hline$\overline{1}$ & 34442.8 & 6011902 & 774643.69 & 3305361.25 & 26 & 14459.0 & 6041903 & 774643.69 & 3305361.25 \\
\hline 2 & 31983.0 & 6120501 & 774643.69 & 3305361.25 & 27 & 13323.0 & 6090524 & 761955.63 & 3308548.75 \\
\hline 3 & 30732.5 & 6040303 & 774643.69 & 3305361.25 & 28 & 12819.7 & 6022407 & 765127.63 & 3308548.75 \\
\hline 4 & 30732.5 & 6040601 & 774643.69 & 3305361.25 & 29 & 12490.0 & 6040422 & 761955.63 & 3308548.75 \\
\hline 5 & 25831.6 & 6090701 & 774643.69 & 3305361.25 & 30 & 12409.5 & 6060101 & 765127.63 & 3308548.75 \\
\hline 6 & 23678.6 & 6042623 & 774643.69 & 3305361.25 & 31 & 12361.5 & 6042104 & 765127.63 & 3308548.75 \\
\hline 7 & 22387.5 & 6122607 & 774643.69 & 3305361.25 & 32 & 12361.5 & 6042221 & 765127.63 & 3308548.75 \\
\hline 8 & 22141.4 & 6111822 & 774643.69 & 3305361.25 & 33 & 12301.2 & 6022701 & 774643.69 & 3305361.25 \\
\hline 9 & 21801.0 & 6091105 & 765127.63 & 3308548.75 & 34 & 12105.0 & 6041606 & 774643.69 & 3305361.25 \\
\hline 10 & 21526.0 & 6021420 & 774643.69 & 3305361.25 & 35 & 11899.0 & 6051002 & 774643.69 & 3305361.25 \\
\hline 11 & 20398.9 & 6060705 & 774643.69 & 3305361.25 & 36 & 11660.4 & 6041006 & 774643.69 & 3305361.25 \\
\hline 12 & 20115.5 & 6010606 & 774643.69 & 3305361.25 & 37 & 11071.0 & 6060323 & 774643.69 & 3305361.25 \\
\hline 13 & 20115.5 & 6011904 & 774643.69 & 3305361.25 & 38 & 10988.2 & 6052604 & 765127.63 & 3308548.75 \\
\hline 14 & 20091.6 & 6090224 & 774643.69 & 3305361.25 & 39 & 10900.1 & 6071902 & 765127.63 & 3308548.75 \\
\hline 15 & 19648.6 & 6120608 & 774643.69 & 3305361.25 & 40 & 10669.9 & 6052805 & 774643.69 & 3305361.25 \\
\hline 16 & 18943.3 & 6042124 & 774643.69 & 3305361.25 & 41 & 10516.0 & 6112919 & 774643.69 & 3305361.25 \\
\hline 17 & 18943.3 & 6042902 & 774643.69 & 3305361.25 & 42 & 10288.5 & 6062223 & 774643.69 & 3305361.25 \\
\hline 18 & 18402.4 & 6090801 & 774643.69 & 3305361.25 & 43 & 10045.8 & 6052505 & 774643.69 & 3305361.25 \\
\hline 19 & 16767.7 & 6010220 & 761955.63 & 3308548.75 & 44 & 9896.70 & 6022424 & 765127.63 & 3308548.75 \\
\hline 20 & 16767.0 & 6040504 & 774643.69 & 3305361.25 & 45 & 9894.00 & 6090219 & 774643.69 & 3305361.25 \\
\hline 21 & 16350.2 & 6091922 & 765127.63 & 3308548.75 & 46 & 9840.90 & 6100401 & 774643.69 & 3305361.25 \\
\hline 22 & 15786.3 & 6042206 & 774643.69 & 3305361.25 & 47 & 9639.70 & 6042905 & 774643.69 & 3305361.25 \\
\hline 23 & 15774.0 & 6060502 & 774643.69 & 3305361.25 & 48 & 9625.20 & 6011705 & 765127.63 & 3308548.75 \\
\hline 24 & 15773.5 & 6110503 & 774643.69 & 3305361.25 & 49 & 9306.80 & 6062923 & 765127.63 & 3308548.75 \\
\hline 25 & 14861.2 & 6120503 & 774643.69 & 3305361.25 & 50 & 9275.60 & 6060524 & 774643.69 & 3305361.25 \\
\hline
\end{tabular}


Am. J. Environ. Sci., 4 (5): 420-438, 2008

Table 5b: ISCST3 output data modeling results for the 50 highest daily average concentrations of non-methane hydrocarbons

\begin{tabular}{|c|c|c|c|c|c|c|c|c|c|}
\hline \multirow[b]{2}{*}{ Rank } & \multirow[b]{2}{*}{$\begin{array}{l}\text { CONC } \\
\left(\mu \mathrm{g} \mathrm{m}^{-1}\right)\end{array}$} & \multirow[b]{2}{*}{ (YYMMDDHH) } & \multicolumn{5}{|c|}{ Location coordinate in UTM (m) } & \multicolumn{2}{|c|}{ Location coordinate in UTM (m) } \\
\hline & & & $\mathrm{X}$ & $\mathrm{Y}$ & Rank & $\begin{array}{l}\mathrm{CONC}_{(\mathrm{i}} \\
\left(\mu \mathrm{g} \mathrm{m}^{-1}\right)\end{array}$ & (YYMMDDHH) & $\mathrm{X}$ & $\mathrm{Y}$ \\
\hline 1 & 3099.8 & 6011924 & 774643.69 & 3305361.3 & 26 & 983.20 & 6062224 & 774643.69 & 3305361 \\
\hline 2 & 2602.5 & 6120524 & 774643.69 & 3305361.3 & 27 & 978.00 & 6090824 & 774643.69 & 3305361 \\
\hline 3 & 1993.7 & 6042924 & 774643.69 & 3305361.3 & 28 & 961.93 & 6100824 & 774643.69 & 3305361 \\
\hline 4 & 1957.5 & 6040624 & 774643.69 & 3305361.3 & 29 & 960.11 & 6091924 & 765127.63 & 3308549 \\
\hline 5 & 1707.4 & 6040324 & 774643.69 & 3305361.3 & 30 & 931.72 & 6010224 & 761955.63 & 3308549 \\
\hline 6 & 1671.8 & 6090224 & 774643.69 & 3305361.3 & 31 & 904.41 & 6040524 & 774643.69 & 3305361 \\
\hline 7 & 1596.2 & 6022724 & 774643.69 & 3305361.3 & 32 & 857.01 & 6120924 & 765127.63 & 3308549 \\
\hline 8 & 1564.4 & 6022424 & 765127.63 & 3308548.8 & 33 & 850.21 & 6060124 & 765127.63 & 3308549 \\
\hline 9 & 1516.0 & 6012924 & 765127.63 & 3308548.8 & 34 & 798.77 & 6010824 & 774643.69 & 3305361 \\
\hline 10 & 1504.6 & 6060524 & 774643.69 & 3305361.3 & 35 & 783.73 & 6113024 & 774643.69 & 3305361 \\
\hline 11 & 1469.2 & 6090724 & 774643.69 & 3305361.3 & 36 & 773.74 & 6012324 & 765127.63 & 3308549 \\
\hline 12 & 1439.9 & 6042224 & 774643.69 & 3305361.3 & 37 & 761.29 & 6041624 & 774643.69 & 3305361 \\
\hline 13 & 1398.7 & 6122624 & 774643.69 & 3305361.3 & 38 & 746.89 & 6012424 & 774643.69 & 3305361 \\
\hline 14 & 1346.0 & 6100424 & 774643.69 & 3305361.3 & 39 & 739.62 & 6022824 & 774643.69 & 3305361 \\
\hline 15 & 1308.5 & 6010624 & 774643.69 & 3305361.3 & 40 & 728.67 & 6012024 & 774643.69 & 3305361 \\
\hline 16 & 1251.3 & 6080824 & 774643.69 & 3305361.3 & 41 & 715.86 & 6101024 & 774643.69 & 3305361 \\
\hline 17 & 1236.8 & 6111824 & 774643.69 & 3305361.3 & 42 & 704.33 & 6092424 & 774643.69 & 3305361 \\
\hline 18 & 1217.0 & 6042124 & 774643.69 & 3305361.3 & 43 & 700.47 & 6122724 & 774643.69 & 3305361 \\
\hline 19 & 1208.3 & 6110524 & 774643.69 & 3305361.3 & 44 & 690.88 & 6102124 & 774643.69 & 3305361 \\
\hline 20 & 1190.1 & 6042624 & 774643.69 & 3305361.3 & 45 & 661.15 & 6042224 & 765127.63 & 3308549 \\
\hline 21 & 1107.3 & 6021424 & 774643.69 & 3305361.3 & 46 & 658.13 & 6041924 & 774643.69 & 3305361 \\
\hline 22 & 1091.7 & 6120624 & 774643.69 & 3305361.3 & 47 & 657.26 & 6041024 & 774643.69 & 3305361 \\
\hline 23 & 1059.5 & 6091124 & 765127.63 & 3308548.8 & 48 & 654.42 & 6041524 & 774643.69 & 3305361 \\
\hline 24 & 1044.7 & 6060724 & 774643.69 & 3305361.3 & 49 & 643.82 & 6071924 & 765127.63 & 3308549 \\
\hline 25 & 1025.7 & 6041124 & 774643.69 & 3305361.3 & 50 & 638.44 & 6100124 & 774643.69 & 3305361 \\
\hline
\end{tabular}

Table 5c: ISCST3 output data modeling results for the 10th highest annual average concentrations of non-methane hydrocarbons

\begin{tabular}{lcll}
\hline & & \multicolumn{2}{l}{ Location Coordinate in UTM (m) } \\
Rank & CONC. $\left(\mu \mathrm{g} \mathrm{m}^{-3}\right)$ & $\mathrm{X}$ & $\mathrm{Y}$ \\
\hline $1 \mathrm{ST}$ & 200.17 & 774643.69 & 3305361.25 \\
2ND & 107.89 & 765127.63 & 3308548.75 \\
3RD & 63.14 & 761955.63 & 3311736.00 \\
$4 \mathrm{TH}$ & 49.68 & 765127.63 & 3305361.25 \\
$5 \mathrm{TH}$ & 38.77 & 761955.63 & 3308548.75 \\
$6 \mathrm{TH}$ & 33.04 & 768299.69 & 3302173.75 \\
$7 \mathrm{TH}$ & 29.04 & 765127.63 & 3311736.00 \\
$8 \mathrm{TH}$ & 27.98 & 768299.69 & 3305361.25 \\
$9 \mathrm{TH}$ & 26.21 & 777815.69 & 3302173.75 \\
$10 \mathrm{TH}$ & 22.79 & 768299.69 & 3308548.75 \\
\hline
\end{tabular}

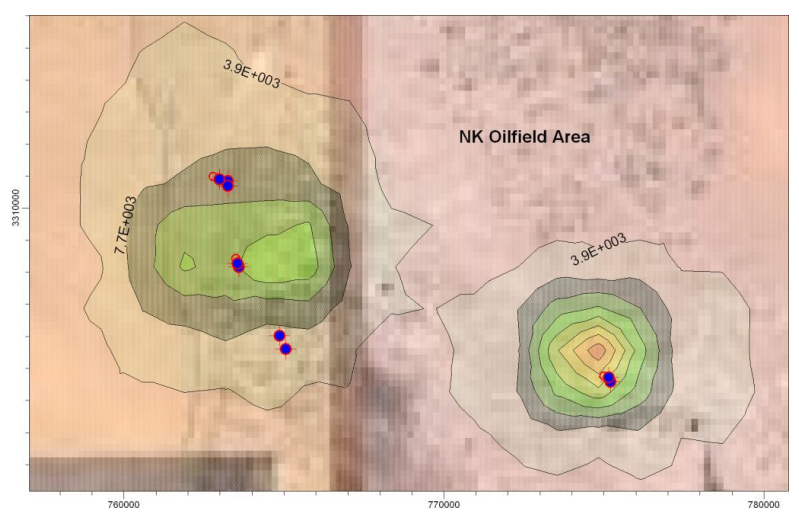

Fig. 9a: Isopleths plot for the maximum hourly average ground level concentrations of non-methane hydrocarbons in $\mu \mathrm{g} \mathrm{m}^{-3}$

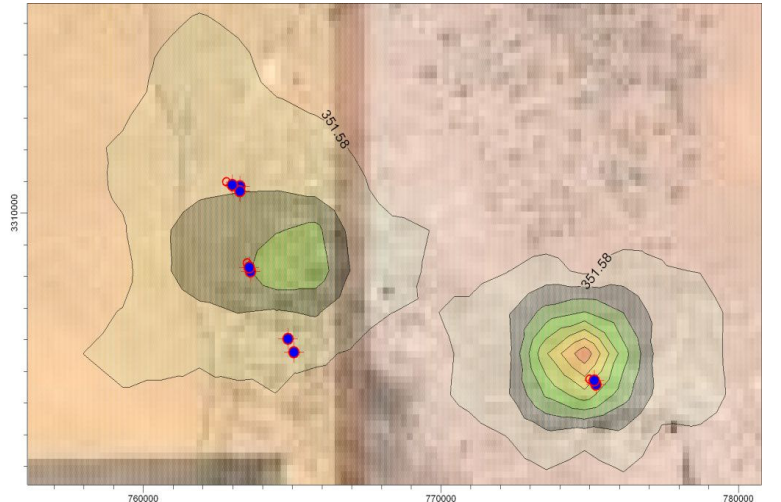

Fig. 9b: Isopleths plot for the maximum hourly average ground level concentrations of non-methane hydrocarbons in $\mu \mathrm{g} \mathrm{m}^{-3}$

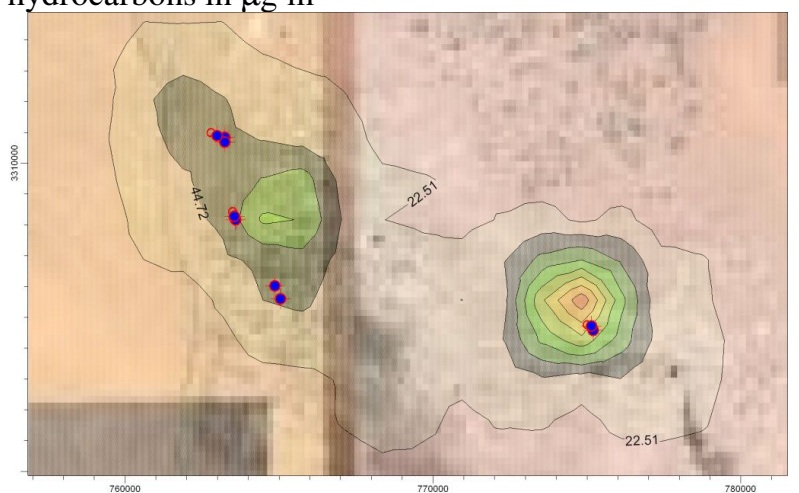

Fig. 9c: Isopleths plot for the maximum annual average ground level concentrations of non-methane hydrocarbons in $\mu \mathrm{g} \mathrm{m}^{-3}$ 
$\mathrm{Y}=3305361.25$. This receptor is located nearly $54 \mathrm{~km}$ in the NNW direction from the centre of the NK Oilfields and not far from the residential areas. For the same location, Table 5c and Fig. 9c show that the highest annual maximum concentration of non-methane hydrocarbons is $200.17 \mu \mathrm{g} \mathrm{m}^{-3}$.

There were some unexpected problems in NK Oilfields in the year 2005 and the amount of gas flared, as a percentage of production, was almost double of the amount recorded from 2004. The above results reflect this, as well as, the increase in flaring in January 2006, due to regular shut down of Condensate Recovery Unit (CRU's) in NK Oilfields and the prevailing wind direction in Kuwait. Considering Table 4a-c, 5a-c and Fig. 8a-c, 9a-c together, it can be concluded the weather pattern in Kuwait in January 2006, especially the mean prevailing wind direction, significantly contributed to high concentrations of methane and non-methane hydrocarbons at ground level in residential areas located downwind of the NK Oilfields.

\section{South and East Kuwait oilfield area results}

Non-methane hydrocarbons emission: Table 6a-c show the modeling results for the 50 highest hourly, 50 highest daily and the 50 highest annual maximum ground level concentrations of non-methane hydrocarbons, respectively calculated at the uniform grid receptors described previously. Isopleths plots (contours) were generated, as show in Fig. 10a-c. These present the maximum hourly, daily and annual ground level concentration of non-methane hydrocarbons in $\mu \mathrm{g} \mathrm{m}^{-3}$ calculated at the specified uniform grid receptors.

As shown in Table 6a the predicted maximum hourly average ground level concentration of nonmethane hydrocarbons in the study area is $5363 \mu \mathrm{g} \mathrm{m}^{-3}$, hour 2:00, 28th January 2006 at the receptor coordinate of $\mathrm{X}=790158.13, \mathrm{Y}=3203288.25$

The predicted maximum daily average ground level concentration of non-methane hydrocarbons in the study area in Table $6 \mathrm{~b}$ is $473.15 \mu \mathrm{g} \mathrm{m}^{-3}$, hour 24:00, 16th January 2006 at the receptor coordinate of $\mathrm{X}=790158.13, \mathrm{Y}=3203288.25$. For the same location, Table $6 \mathrm{c}$ and Fig. 10c show that the highest annual maximum concentration of non-methane hydrocarbons is $17.943 \mu \mathrm{g} \mathrm{m}^{-3}$.

Methane emission: Table 7a-c show the modeling results for the 50 highest hourly, 50 highest daily and the 50 highest annual maximum ground level concentrations of methane, respectively calculated at the uniform grid

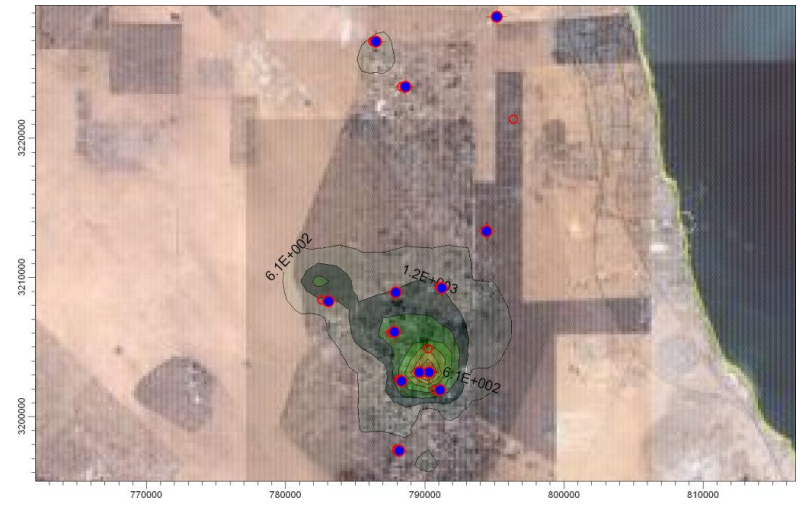

Fig. 10a: Isopleths plot for the maximum hourly average ground level concentrations of nonmethane hydrocarbons in $\mu \mathrm{g}-\mathrm{m}^{3}$

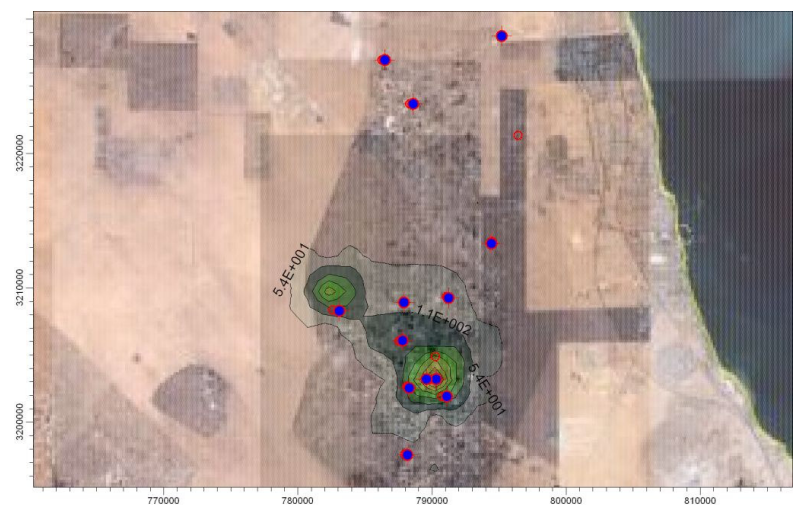

Fig. 10b: Isopleths plot for the maximum hourly average ground level concentrations of nonmethane hydrocarbons in $\mu \mathrm{g} \mathrm{m}^{-3}$

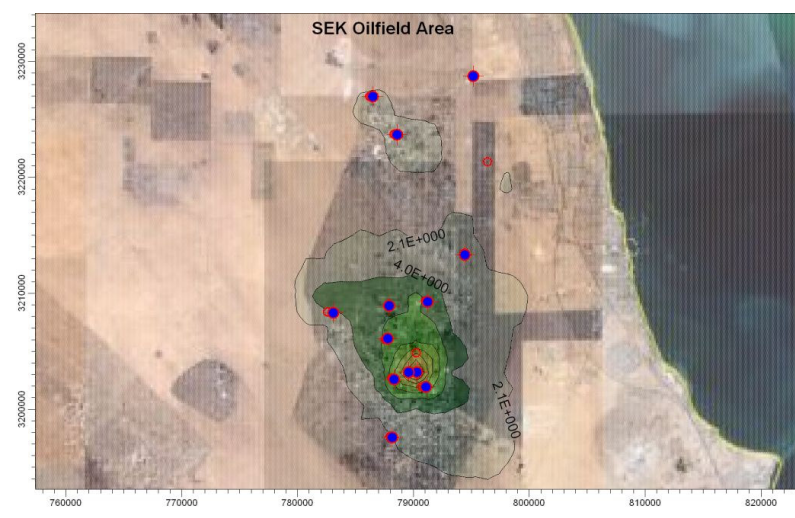

Fig. 10c: Isopleths plot for the maximum annual average ground level concentrations of nonmethane hydrocarbons in $\mu \mathrm{g} \mathrm{m}^{-3}$ 
Am. J. Environ. Sci., 4 (5): 420-438, 2008

Table 6a: ISCST3 output data modeling results for the 50 highest hourly average concentrations of non-methane hydrocarbons

\begin{tabular}{|c|c|c|c|c|c|c|c|c|c|}
\hline \multirow[b]{2}{*}{ Rank } & \multirow{2}{*}{$\begin{array}{l}\text { CONC. } \\
\left(\mu \mathrm{g} \mathrm{m}^{-1}\right)\end{array}$} & \multirow[b]{2}{*}{ (YYMMDDHH) } & \multicolumn{2}{|c|}{$\begin{array}{l}\text { Location coordinate in } \\
\text { UTM }(m)\end{array}$} & \multirow[b]{2}{*}{ Rank } & \multirow{2}{*}{$\begin{array}{l}\text { CONC. } \\
\left(\mu \mathrm{g} \mathrm{m}^{-1}\right)\end{array}$} & \multirow[b]{2}{*}{ (YYMMDDHH) } & \multicolumn{2}{|c|}{$\begin{array}{l}\text { Location coordinate in } \\
\text { UTM }(m)\end{array}$} \\
\hline & & & $\mathrm{X}$ & $\mathrm{Y}$ & & & & $\mathrm{X}$ & $\mathrm{Y}$ \\
\hline 1 & 5363.0 & 6012802 & 790158.13 & 3203288.25 & 26 & 1125.3 & 6052023 & 790158.13 & 3209777.50 \\
\hline 2 & 4841.0 & 6011605 & 790158.13 & 3203288.25 & 27 & 1089.7 & 6122319 & 786283.06 & 3206532.75 \\
\hline 3 & 4501.3 & 6011609 & 790158.13 & 3203288.25 & 28 & 1034.8 & 6062302 & 782408.00 & 3209777.50 \\
\hline 4 & 3824.7 & 6010222 & 790158.13 & 3203288.25 & 29 & 1032.7 & 6062221 & 782408.00 & 3209777.50 \\
\hline 5 & 3118.6 & 6011306 & 790158.13 & 3203288.25 & 30 & 1027.8 & 6022320 & 790158.13 & 3203288.25 \\
\hline 6 & 2270.7 & 6012803 & 790158.13 & 3203288.25 & 31 & 984.00 & 6022222 & 790158.13 & 3203288.25 \\
\hline 7 & 2093.5 & 6060222 & 782408.00 & 3209777.50 & 32 & 967.90 & 6052804 & 790158.13 & 3206532.75 \\
\hline 8 & 1962.3 & 6081904 & 786283.06 & 3206532.75 & 33 & 917.70 & 6060202 & 782408.00 & 3209777.50 \\
\hline 9 & 1913.8 & 6052023 & 790158.13 & 3206532.75 & 34 & 897.00 & 6051422 & 790158.13 & 3203288.25 \\
\hline 10 & 1880.7 & 6052802 & 790158.13 & 3206532.75 & 35 & 888.30 & 6050202 & 794033.19 & 3206532.75 \\
\hline 11 & 1869.8 & 6062305 & 782408.00 & 3209777.50 & 36 & 888.30 & 6051503 & 794033.19 & 3206532.75 \\
\hline 12 & 1793.4 & 6060306 & 790158.13 & 3203288.25 & 37 & 860.60 & 6060522 & 782408.00 & 3209777.50 \\
\hline 13 & 1702.9 & 6012308 & 790158.13 & 3203288.25 & 38 & 857.10 & 6120621 & 786283.06 & 3226000.50 \\
\hline 14 & 1674.8 & 6060201 & 782408.00 & 3209777.50 & 39 & 856.50 & 6022507 & 790158.13 & 3203288.25 \\
\hline 15 & 1674.8 & 6060723 & 782408.00 & 3209777.50 & 40 & 851.30 & 6052005 & 790158.13 & 3203288.25 \\
\hline 16 & 1616.0 & 6011421 & 790158.13 & 3203288.25 & 41 & 838.60 & 6120504 & 786283.06 & 3209777.50 \\
\hline 17 & 1563.6 & 6060403 & 790158.13 & 3203288.25 & 42 & 819.60 & 6122801 & 786283.06 & 3209777.50 \\
\hline 18 & 1473.6 & 6011422 & 790158.13 & 3203288.25 & 43 & 815.50 & 6081303 & 786283.06 & 3206532.75 \\
\hline 19 & 1345.5 & 6050324 & 790158.13 & 3203288.25 & 44 & 797.40 & 6051119 & 790158.13 & 3203288.25 \\
\hline 20 & 1343.9 & 6050904 & 790158.13 & 3206532.75 & 45 & 790.70 & 6050921 & 790158.13 & 3206532.75 \\
\hline 21 & 1323.5 & 6060301 & 790158.13 & 3203288.25 & 46 & 781.80 & 6051624 & 786283.06 & 3209777.50 \\
\hline 22 & 1323.5 & 6062806 & 790158.13 & 3203288.25 & 47 & 781.80 & 6051724 & 786283.06 & 3209777.50 \\
\hline 23 & 1260.9 & 6120201 & 790158.13 & 3209777.50 & 48 & 767.70 & 6050820 & 790158.13 & 3209777.50 \\
\hline 24 & 1166.8 & 6062301 & 790158.13 & 3206532.75 & 49 & 765.40 & 6050720 & 786283.06 & 3200043.50 \\
\hline 25 & 1137.6 & 6122522 & 790158.13 & 3209777.50 & 50 & 764.10 & 6081923 & 790158.13 & 3209777.50 \\
\hline
\end{tabular}

Table 6b: ISCST3 output data modeling results for the 50 highest daily average concentrations of non-methane hydrocarbons

\begin{tabular}{|c|c|c|c|c|c|c|c|c|c|}
\hline \multirow[b]{2}{*}{ Rank } & \multirow[b]{2}{*}{$\begin{array}{l}\mathrm{CONC}_{\mathrm{i}} \\
\left(\mu \mathrm{g} \mathrm{m}^{-1}\right)\end{array}$} & \multirow{2}{*}{$\begin{array}{l}\text { in UTM (m) } \\
\text { (YYMMDDHH) }\end{array}$} & \multicolumn{4}{|c|}{ Location coordinate } & \multirow{2}{*}{$\begin{array}{l}\text { in UTM (m) } \\
\text { (YYMMDDHH) }\end{array}$} & \multicolumn{2}{|c|}{ Location coordinate in } \\
\hline & & & $\mathrm{X}$ & $\mathrm{Y}$ & Rank & $\begin{array}{l}\text { CONC }_{i} \\
\left(\mu \mathrm{g} \mathrm{m}^{-1}\right)\end{array}$ & & $X$ & $\mathrm{Y}$ \\
\hline 1 & 473.15 & 6011624 & 790158.13 & 3203288.25 & 26 & 68.452 & 6051124 & 790158.13 & 3203288.25 \\
\hline 2 & 437.21 & 6012824 & 790158.13 & 3203288.25 & 27 & 67.492 & 6090224 & 790158.13 & 3203288.25 \\
\hline 3 & 300.76 & 6060224 & 782408.00 & 3209777.5 & 28 & 67.388 & 6080724 & 790158.13 & 3203288.25 \\
\hline 4 & 221.51 & 6010224 & 790158.13 & 3203288.25 & 29 & 67.377 & 6120224 & 790158.13 & 3209777.50 \\
\hline 5 & 173.01 & 6060324 & 790158.13 & 3203288.25 & 30 & 66.431 & 6050224 & 790158.13 & 3203288.25 \\
\hline 6 & 170.67 & 6011324 & 790158.13 & 3203288.25 & 31 & 66.254 & 6060524 & 782408.00 & 3209777.50 \\
\hline 7 & 164.52 & 6062324 & 782408.00 & 3209777.5 & 32 & 65.009 & 6062824 & 790158.13 & 3203288.25 \\
\hline 8 & 149.51 & 6011424 & 790158.13 & 3203288.25 & 33 & 63.242 & 6050724 & 786283.06 & 3200043.50 \\
\hline 9 & 136.67 & 6081924 & 786283.06 & 3206532.75 & 34 & 62.776 & 6122324 & 786283.06 & 3206532.75 \\
\hline 10 & 128.76 & 6052824 & 790158.13 & 3206532.75 & 35 & 62.759 & 6081924 & 790158.13 & 3209777.50 \\
\hline 11 & 124.52 & 6050924 & 790158.13 & 3206532.75 & 36 & 62.325 & 6120924 & 790158.13 & 3203288.25 \\
\hline 12 & 107.87 & 6073124 & 790158.13 & 3203288.25 & 37 & 61.972 & 6122624 & 786283.06 & 3209777.50 \\
\hline 13 & 103.05 & 6012324 & 790158.13 & 3203288.25 & 38 & 61.421 & 6121224 & 790158.13 & 3203288.25 \\
\hline 14 & 102.61 & 6060424 & 790158.13 & 3203288.25 & 39 & 60.210 & 6060224 & 794033.19 & 3216266.50 \\
\hline 15 & 92.28 & 6060724 & 782408.00 & 3209777.5 & 40 & 59.873 & 6062224 & 782408.00 & 3209777.50 \\
\hline 16 & 90.41 & 6042124 & 790158.13 & 3203288.25 & 41 & 58.442 & 6021524 & 790158.13 & 3196799.00 \\
\hline 17 & 90.30 & 6062324 & 790158.13 & 3206532.75 & 42 & 58.091 & 6032424 & 790158.13 & 3203288.25 \\
\hline 18 & 86.85 & 6022524 & 790158.13 & 3203288.25 & 43 & 57.849 & 6042024 & 790158.13 & 3203288.25 \\
\hline 19 & 86.25 & 6022224 & 790158.13 & 3203288.25 & 44 & 57.177 & 6122524 & 790158.13 & 3209777.50 \\
\hline 20 & 83.06 & 6052024 & 790158.13 & 3206532.75 & 45 & 57.159 & 6051724 & 786283.06 & 3209777.50 \\
\hline 21 & 82.22 & 6120224 & 790158.13 & 3203288.25 & 46 & 56.912 & 6030324 & 790158.13 & 3203288.25 \\
\hline 22 & 82.02 & 6051424 & 790158.13 & 3203288.25 & 47 & 56.626 & 6010124 & 790158.13 & 3203288.25 \\
\hline 23 & 81.04 & 6022324 & 790158.13 & 3203288.25 & 48 & 56.570 & 6082324 & 790158.13 & 3206532.75 \\
\hline 24 & 80.41 & 6052024 & 790158.13 & 3209777.5 & 49 & 55.211 & 6052024 & 790158.13 & 3203288.25 \\
\hline 25 & 76.19 & 6050324 & 790158.13 & 3203288.25 & 50 & 54.337 & 6120524 & 794033.19 & 3213022.00 \\
\hline
\end{tabular}

receptors described previously. Isopleths plots (contours) were generated, as shown in Fig. 11a-c. These present the maximum hourly, daily and annual ground level concentration of methane in $\mu \mathrm{g} \mathrm{m}^{-3}$ calculated at the specified uniform grid receptors. 
Am. J. Environ. Sci., 4 (5): 420-438, 2008

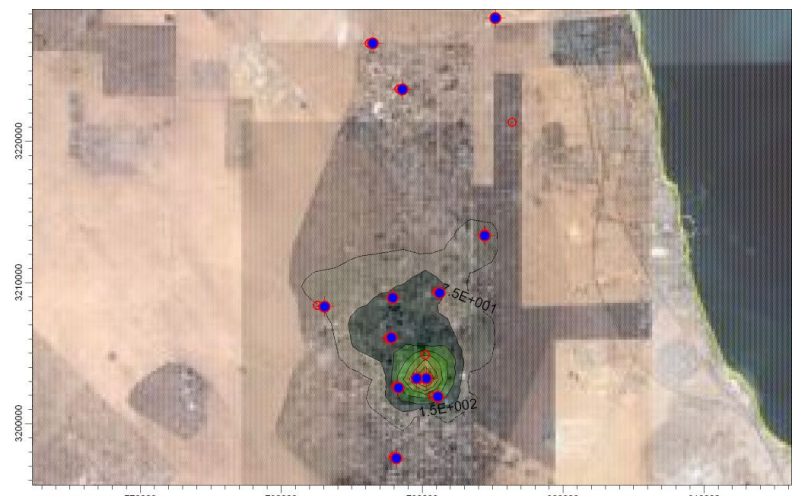

Fig. 11a: Isopleths plot for the maximum hourly average ground level concentrations of methane in $\mu \mathrm{g} \mathrm{m}^{-3}$

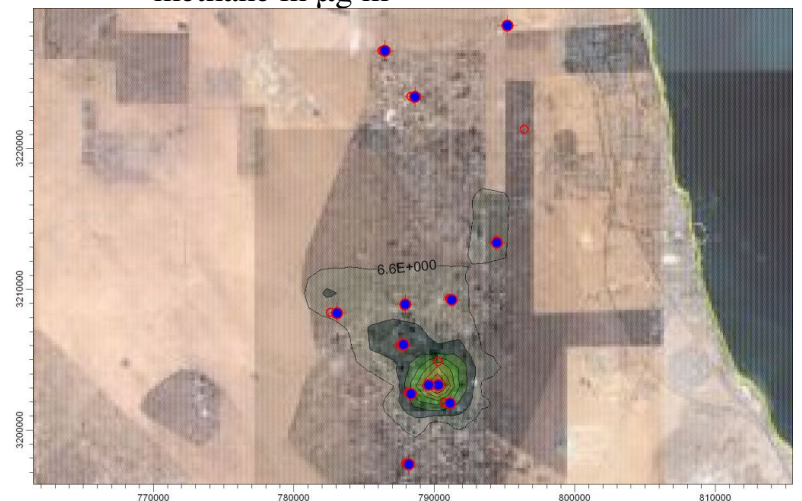

Fig. 11b: Isopleths plot for the maximum hourly average ground level concentrations of methane in $\mu \mathrm{g}$ $\mathrm{m}^{-3}$

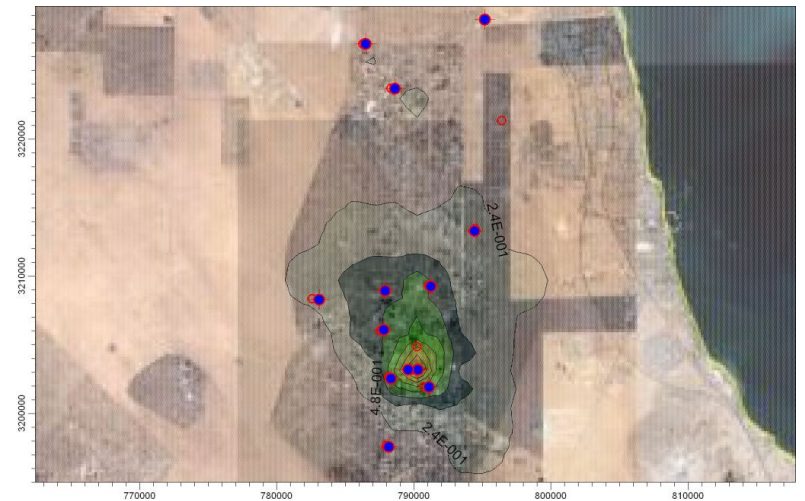

Fig. 11c: Isopleths plot for the maximum annual average ground level concentrations of methane in $\mu \mathrm{g} \mathrm{m}^{-3}$

Table 6c: ISCST3 output data modeling results for the 10th highest annual average concentrations of non-methane hydrocarbons

\begin{tabular}{|c|c|c|c|}
\hline \multirow[b]{2}{*}{ Rank } & \multirow[b]{2}{*}{$\begin{array}{l}\text { CONC. } \\
\left(\mu \mathrm{g} \mathrm{m}^{-3}\right)\end{array}$} & \multicolumn{2}{|c|}{ Location Coordinate in UTM (m) } \\
\hline & & $\mathrm{X}$ & Y \\
\hline $1 \mathrm{ST}$ & 17.943 & 790158.13 & 3203288.25 \\
\hline $2 \mathrm{ND}$ & 7.664 & 790158.13 & 3206532.75 \\
\hline 3RD & 6.447 & 790158.13 & 3209777.50 \\
\hline $4 \mathrm{TH}$ & 5.869 & 782408.00 & 3209777.50 \\
\hline $5 \mathrm{TH}$ & 5.429 & 786283.06 & 3206532.75 \\
\hline $6 \mathrm{TH}$ & 5.133 & 786283.06 & 3209777.50 \\
\hline $7 \mathrm{TH}$ & 4.082 & 794033.19 & 3200043.50 \\
\hline $8 \mathrm{TH}$ & 4.014 & 790158.13 & 3200043.50 \\
\hline 9TH & 3.960 & 790158.13 & 3222755.75 \\
\hline $10 \mathrm{TH}$ & 3.776 & 786283.06 & 3203288.25 \\
\hline
\end{tabular}

Table 7a: ISCST3 output data modeling results for the 50 highest hourly average concentrations of methane

\begin{tabular}{|c|c|c|c|c|c|c|c|c|c|}
\hline \multirow[b]{2}{*}{ Rank } & \multirow[b]{2}{*}{$\begin{array}{l}\text { CONC } \\
\left(\mu \mathrm{g} \mathrm{m}^{-1}\right)\end{array}$} & \multirow[b]{2}{*}{ (YYMMDDHH) } & \multicolumn{5}{|c|}{ Location coordinate in UTM (m) } & \multicolumn{2}{|c|}{ Location coordinate in UTM (m) } \\
\hline & & & $\mathrm{X}$ & $\mathrm{Y}$ & Rank & $\left(\mu \mathrm{g} \mathrm{m}^{-1}\right)$ & (YYMMDDHH) & $\mathrm{X}$ & $\mathrm{Y}$ \\
\hline 1 & 655.48 & 6012802 & 790158.13 & 3203288.25 & 26 & 114.04 & 6122623 & 786283.06 & 3209777.50 \\
\hline 2 & 591.66 & 6011605 & 790158.13 & 3203288.25 & 27 & 104.77 & 6121324 & 790158.13 & 3206532.75 \\
\hline 3 & 550.10 & 6011609 & 790158.13 & 3203288.25 & 28 & 104.69 & 6022507 & 790158.13 & 3203288.25 \\
\hline 4 & 467.41 & 6010222 & 790158.13 & 3203288.25 & 29 & 102.08 & 6050324 & 790158.13 & 3203288.25 \\
\hline 5 & 381.15 & 6011306 & 790158.13 & 3203288.25 & 30 & 101.12 & 6050904 & 790158.13 & 3206532.75 \\
\hline 6 & 277.53 & 6012803 & 790158.13 & 3203288.25 & 31 & 98.520 & 6060222 & 782408.00 & 3209777.50 \\
\hline 7 & 240.39 & 6081904 & 786283.06 & 3206532.75 & 32 & 96.940 & 6081303 & 786283.06 & 3206532.75 \\
\hline 8 & 219.01 & 6060306 & 790158.13 & 3203288.25 & 33 & 93.740 & 6120522 & 794033.19 & 3213022.00 \\
\hline 9 & 208.14 & 6012308 & 790158.13 & 3203288.25 & 34 & 93.060 & 6120222 & 790158.13 & 3203288.25 \\
\hline 10 & 197.38 & 6011421 & 790158.13 & 3203288.25 & 35 & 92.010 & 6120904 & 790158.13 & 3203288.25 \\
\hline 11 & 196.69 & 6120201 & 790158.13 & 3209777.50 & 36 & 89.580 & 6062301 & 790158.13 & 3206532.75 \\
\hline 12 & 190.99 & 6060403 & 790158.13 & 3203288.25 & 37 & 88.970 & 6121202 & 790158.13 & 3209777.50 \\
\hline 13 & 178.14 & 6011422 & 790158.13 & 3203288.25 & 38 & 87.990 & 6062305 & 782408.00 & 3209777.50 \\
\hline 14 & 177.47 & 6122522 & 790158.13 & 3209777.50 & 39 & 86.440 & 6012110 & 790158.13 & 3203288.25 \\
\hline 15 & 168.72 & 6122319 & 786283.06 & 3206532.75 & 40 & 85.980 & 6031302 & 790158.13 & 3206532.75 \\
\hline 16 & 161.77 & 6060301 & 790158.13 & 3203288.25 & 41 & 85.380 & 6100807 & 782408.00 & 3209777.50 \\
\hline 17 & 161.77 & 6062806 & 790158.13 & 3203288.25 & 42 & 84.750 & 6052023 & 790158.13 & 3209777.50 \\
\hline 18 & 143.59 & 6052023 & 790158.13 & 3206532.75 & $4 \overline{3}$ & 84.580 & 6120221 & 790158.13 & 3203288.25 \\
\hline 19 & 141.62 & 6052802 & 790158.13 & 3206532.75 & 44 & 84.330 & 6082107 & 790158.13 & 3203288.25 \\
\hline 20 & 130.82 & 6120504 & 786283.06 & 3209777.50 & 45 & 83.060 & 6050820 & 790158.13 & 3209777.50 \\
\hline 21 & 127.85 & 6122801 & 786283.06 & 3209777.50 & 46 & 82.890 & 6120621 & 786283.06 & 3226000.50 \\
\hline 22 & 125.62 & 6022320 & 790158.13 & 3203288.25 & 47 & 82.660 & 6081923 & 790158.13 & 3209777.50 \\
\hline 23 & 120.27 & 6022222 & 790158.13 & 3203288.25 & 48 & 80.650 & 6010222 & 790158.13 & 3209777.50 \\
\hline 24 & 118.10 & 6121919 & 790158.13 & 3209777.50 & 49 & 80.570 & 6022504 & 790158.13 & 3203288.25 \\
\hline 25 & 118.05 & 6060403 & 790158.13 & 3209777.50 & 50 & 78.820 & 6060201 & 782408.00 & 3209777.50 \\
\hline
\end{tabular}


Am. J. Environ. Sci., 4 (5): 420-438, 2008

Table 7b: ISCST3 output data modeling results for the 50 highest daily average concentrations of methane

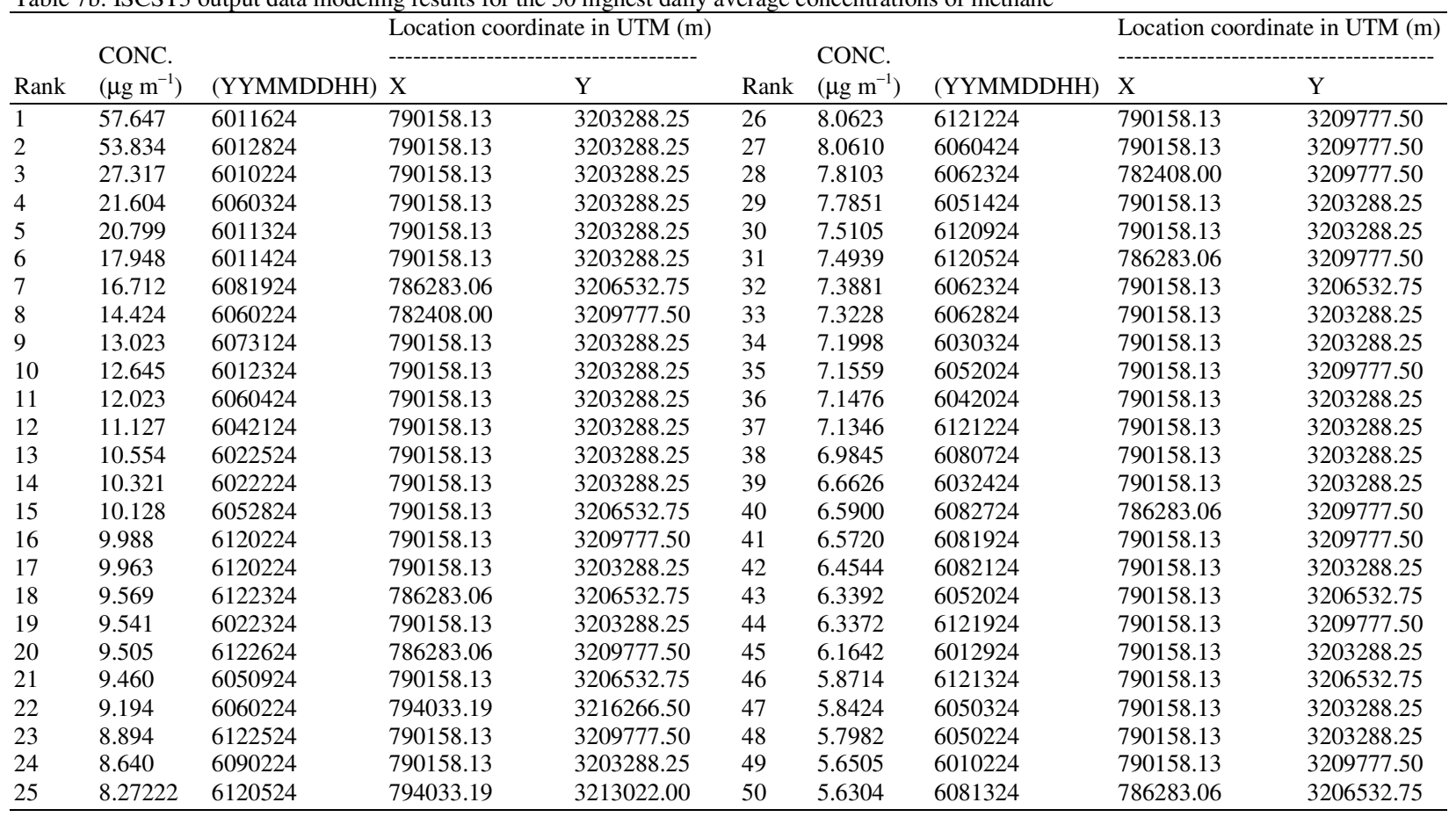

Table 7c: ISCST3 output data modeling results for the 10th highest annual average concentrations of methane

\begin{tabular}{llll}
\hline & & \multicolumn{2}{l}{ Location coordinate in UTM $(\mathrm{m})$} \\
Rank & $\begin{array}{l}\text { CONC. } \\
\left(\mu \mathrm{g} \mathrm{m}^{-3}\right)\end{array}$ & $\mathrm{X}$ & $\mathrm{Y}$ \\
\hline 1ST & 2.1248 & 790158.13 & 3203288.25 \\
2ND & 0.9741 & 790158.13 & 3206532.75 \\
3RD & 0.8148 & 790158.13 & 3209777.50 \\
4TH & 0.6234 & 786283.06 & 3209777.50 \\
5TH & 0.5387 & 786283.06 & 3206532.75 \\
6TH & 0.4309 & 794033.19 & 3200043.50 \\
7TH & 0.4194 & 782408.00 & 3209777.50 \\
8TH & 0.3830 & 794033.19 & 3203288.25 \\
9TH & 0.3763 & 794033.19 & 3206532.75 \\
10TH & 0.3579 & 786283.06 & 3213022.00 \\
\hline
\end{tabular}

As shown in Table $7 \mathrm{a}$ the predicted maximum hourly average ground level concentration of methane in the study area is $655.48 \mu \mathrm{g} \mathrm{m}^{-3}$, hour 2:00, 28th January 2006 at the receptor coordinate of $\mathrm{X}=790158.13, \mathrm{Y}=3203288.25$.

The predicted maximum daily average ground level concentration of methane in the study area in Table $7 \mathrm{~b}$ is $57.647 \mu \mathrm{g} \mathrm{m} \mathrm{m}^{-3}$, hour 24:00, 16th January 2006 at the a receptor coordinate of $\mathrm{X}=790158.13$, $\mathrm{Y}=3203288.25$. For the same location, Table $7 \mathrm{c}$ and Fig. 11c show that the highest annual maximum concentration of methane is $2.125 \mu \mathrm{g} \mathrm{m}^{-3}$.

The main reasons for high levels of methane and non-methane hydrocarbons encountered in the above results is the increased amount of flaring in January
2006 resulting from frequent shutdowns of CRU's, shortage of gas compression facilities and malfunction of the BS's in SEK Oilfields. Again, these data given strong indication regarding the significant influence prevailing wind direction on the ground level concentrations of methane and non-methane hydrocarbons.

\section{West Kuwait oilfield area results}

Non-methane hydrocarbons emission: Table 8a-c show the modeling results for the 50 highest hourly, 50 highest daily and the 50 highest annual maximum ground level concentrations of non-methane hydrocarbons, respectively calculated at the uniform grid receptors described previously. Isopleths plots (contours) were generated, as show in Fig. 12a-c. These present the maximum hourly, daily and annual ground level concentration of non-methane hydrocarbons in $\mu \mathrm{g} \mathrm{m}^{-3}$ calculated at the specified uniform grid receptors.

As shown in Table $8 \mathrm{a}$ the predicted maximum hourly average ground level concentration of nonmethane hydrocarbons in the study area is $3485.2 \mu \mathrm{g} \mathrm{m}^{-3}$, hour 15:00, 25th August 2006 at the receptor coordinate of $\mathrm{X}=766258.06, \mathrm{Y}=$ 3192914.25.

The predicted maximum daily average ground level concentration of non-methane hydrocarbons in 
Am. J. Environ. Sci., 4 (5): 420-438, 2008

Table 8a: ISCST3 output data modeling results for the 50 highest hourly average concentrations of non-methane hydrocarbons

\begin{tabular}{|c|c|c|c|c|c|c|c|c|c|}
\hline \multirow[b]{2}{*}{ Rank } & \multirow[b]{2}{*}{$\begin{array}{l}\text { CONC. } \\
\left(\mu \mathrm{g} \mathrm{m}^{-1}\right)\end{array}$} & \multirow[b]{2}{*}{ (YYMMDDHH) } & \multicolumn{2}{|c|}{ Location coordinate in UTM (m) } & \multirow[b]{2}{*}{ Rank } & \multirow[b]{2}{*}{$\begin{array}{l}\text { CONC. } \\
\left(\mu \mathrm{g} \mathrm{m}^{-1}\right)\end{array}$} & \multirow[b]{2}{*}{ (YYMMDDHH) } & \multicolumn{2}{|c|}{ Location coordinate in UTM (m) } \\
\hline & & & $\mathrm{X}$ & $\mathrm{Y}$ & & & & $\mathrm{X}$ & $\mathrm{Y}$ \\
\hline$\overline{1}$ & 3485.2 & 6082515 & 766258.06 & 3192914.25 & 26 & 1813.7 & 6081119 & 758013.31 & 3195557.75 \\
\hline 2 & 3368.0 & 6082010 & 766258.06 & 3192914.25 & 27 & 1788.7 & 6081611 & 766258.06 & 3192914.25 \\
\hline 3 & 3354.5 & 6082508 & 766258.06 & 3192914.25 & 28 & 1778.0 & 6082509 & 766258.06 & 3192914.25 \\
\hline 4 & 3077.2 & 6080710 & 766258.06 & 3192914.25 & 29 & 1776.4 & 6082207 & 769006.31 & 3192914.25 \\
\hline 5 & 2679.4 & 6082810 & 766258.06 & 3192914.25 & 30 & 1771.2 & 6102715 & 766258.06 & 3192914.25 \\
\hline 6 & 2400.9 & 6081308 & 766258.06 & 3192914.25 & 31 & 1748.3 & 6081119 & 755265.13 & 3195557.75 \\
\hline 7 & 2395.5 & 6080609 & 766258.06 & 3192914.25 & 32 & 1741.6 & 6082212 & 766258.06 & 3192914.25 \\
\hline 8 & 2374.9 & 6080812 & 766258.06 & 3192914.25 & 33 & 1705.8 & 6092209 & 766258.06 & 3192914.25 \\
\hline 9 & 2204.5 & 6090209 & 766258.06 & 3192914.25 & 34 & 1698.9 & 6082812 & 749768.63 & 3214061.00 \\
\hline 10 & 2155.3 & 6080207 & 771754.56 & 3198201.00 & 35 & 1679.9 & 6092612 & 766258.06 & 3192914.25 \\
\hline 11 & 2129.5 & 6081517 & 763509.81 & 3192914.25 & 36 & 1672.5 & 6082612 & 749768.63 & 3214061.00 \\
\hline 12 & 2124.0 & 6071313 & 766258.06 & 3192914.25 & 37 & 1672.1 & 6082811 & 749768.63 & 3214061.00 \\
\hline 13 & 2079.1 & 6080617 & 766258.06 & 3192914.25 & 38 & 1621.8 & 6081018 & 760761.56 & 3192914.25 \\
\hline 14 & 2057.2 & 6082414 & 766258.06 & 3192914.25 & 39 & 1619.8 & 6101111 & 766258.06 & 3192914.25 \\
\hline 15 & 2051.2 & 6090710 & 766258.06 & 3195557.75 & 40 & 1607.2 & 6073116 & 766258.06 & 3192914.25 \\
\hline 16 & 2029.1 & 6082112 & 766258.06 & 3192914.25 & 41 & 1601.2 & 6082410 & 766258.06 & 3192914.25 \\
\hline 17 & 1994.3 & 6082516 & 763509.81 & 3195557.75 & 42 & 1600.1 & 6080507 & 769006.31 & 3195557.75 \\
\hline 18 & 1981.6 & 6070407 & 771754.56 & 3195557.75 & 43 & 1588.8 & 6070415 & 766258.06 & 3192914.25 \\
\hline 19 & 1916.9 & 6072212 & 766258.06 & 3192914.25 & 44 & 1587.0 & 6081115 & 766258.06 & 3192914.25 \\
\hline 20 & 1847.2 & 6082416 & 766258.06 & 3192914.25 & 45 & 1583.0 & 6081211 & 766258.06 & 3192914.25 \\
\hline 21 & 1841.2 & 6080814 & 766258.06 & 3192914.25 & 46 & 1576.1 & 6081408 & 769006.31 & 3190271.00 \\
\hline 22 & 1838.6 & 6082808 & 769006.31 & 3195557.75 & 47 & 1542.6 & 6070407 & 774502.75 & 3195557.75 \\
\hline 23 & 1832.1 & 6073108 & 769006.31 & 3195557.75 & 48 & 1523.7 & 6072612 & 766258.06 & 3192914.25 \\
\hline 24 & 1821.4 & 6081006 & 769006.31 & 3192914.25 & 49 & 1505.0 & 6091717 & 766258.06 & 3192914.25 \\
\hline 25 & 1814.3 & 6081118 & 763509.81 & 3192914.25 & 50 & 1488.5 & 6070312 & 766258.06 & 3192914.25 \\
\hline
\end{tabular}

Table 8b: ISCST3 output data modeling results for the 50 highest daily average concentrations of non-methane hydrocarbons

\begin{tabular}{|c|c|c|c|c|c|c|c|c|c|}
\hline \multirow[b]{2}{*}{ Rank } & \multirow{2}{*}{$\begin{array}{l}\text { CONC. } \\
\left(\mu \mathrm{g} \mathrm{m}^{-1}\right)\end{array}$} & \multirow[b]{2}{*}{ (YYMMDDHH) } & \multicolumn{2}{|c|}{ Location coordinate in UTM (m) } & \multirow[b]{2}{*}{ Rank } & \multirow{2}{*}{$\begin{array}{l}\text { CONC. } \\
\left(\mu \mathrm{g} \mathrm{m}^{-1}\right)\end{array}$} & \multirow[b]{2}{*}{ (YYMMDDHH) } & \multicolumn{2}{|c|}{ Location coordinate in UTM (m) } \\
\hline & & & $\mathrm{X}$ & $\mathrm{Y}$ & & & & $\mathrm{X}$ & $\mathrm{Y}$ \\
\hline 1 & 492.17 & 6082524 & 766258.06 & 3192914.25 & 26 & 198.25 & 6091724 & 766258.06 & 3190271.00 \\
\hline 2 & 467.97 & 6082424 & 766258.06 & 3192914.25 & 27 & 197.94 & 6090724 & 766258.06 & 3195557.75 \\
\hline 3 & 360.05 & 6080324 & 769006.31 & 3190271.00 & 28 & 197.87 & 6072624 & 771754.56 & 3184984.25 \\
\hline 4 & 355.36 & 6070824 & 769006.31 & 3190271.00 & 29 & 197.59 & 6081124 & 766258.06 & 3192914.25 \\
\hline 5 & 328.49 & 6080624 & 766258.06 & 3192914.25 & 30 & 195.32 & 6072824 & 771754.56 & 3187627.50 \\
\hline 6 & 302.04 & 6080324 & 771754.56 & 3187627.50 & 31 & 193.49 & 6070724 & 769006.31 & 3190271.00 \\
\hline 7 & 295.17 & 6072024 & 769006.31 & 3190271.00 & 32 & 191.29 & 6072224 & 766258.06 & 3192914.25 \\
\hline 8 & 288.18 & 6092224 & 766258.06 & 3192914.25 & 33 & 189.96 & 6080824 & 766258.06 & 3192914.25 \\
\hline 9 & 274.19 & 6072724 & 771754.56 & 3187627.50 & 34 & 189.02 & 6080124 & 769006.31 & 3190271.00 \\
\hline 10 & 267.53 & 6091724 & 766258.06 & 3192914.25 & 35 & 188.85 & 6082024 & 766258.06 & 3192914.25 \\
\hline 11 & 262.78 & 6071224 & 769006.31 & 3192914.25 & 36 & 187.99 & 6050724 & 766258.06 & 3192914.25 \\
\hline 12 & 255.87 & 6080524 & 769006.31 & 3190271.00 & 37 & 186.24 & 6090424 & 769006.31 & 3190271.00 \\
\hline 13 & 255.65 & 6072724 & 769006.31 & 3190271.00 & 38 & 186.20 & 6080324 & 752516.88 & 3211417.75 \\
\hline 14 & 246.50 & 6071624 & 769006.31 & 3190271.00 & 39 & 186.06 & 6092324 & 766258.06 & 3192914.25 \\
\hline 15 & 241.79 & 6072624 & 766258.06 & 3192914.25 & 40 & 183.57 & 6080524 & 771754.56 & 3187627.50 \\
\hline 16 & 239.11 & 6071824 & 769006.31 & 3190271.00 & 41 & 183.46 & 6073124 & 769006.31 & 3195557.75 \\
\hline 17 & 233.31 & 6072824 & 769006.31 & 3190271.00 & 42 & 182.48 & 6072024 & 771754.56 & 3190271.00 \\
\hline 18 & 229.73 & 6082824 & 749768.63 & 3214061.00 & 43 & 182.15 & 6071924 & 766258.06 & 3192914.25 \\
\hline 19 & 216.64 & 6072724 & 774502.75 & 3184984.25 & 44 & 181.75 & 6070924 & 769006.31 & 3190271.00 \\
\hline 20 & 214.42 & 6071024 & 771754.56 & 3190271.00 & 45 & 181.74 & 6091024 & 766258.06 & 3192914.25 \\
\hline 21 & 208.90 & 6082824 & 766258.06 & 3192914.25 & 46 & 181.57 & 6070824 & 771754.56 & 3187627.50 \\
\hline 22 & 206.61 & 6080324 & 774502.75 & 3184984.25 & 47 & 180.85 & 6081024 & 769006.31 & 3192914.25 \\
\hline 23 & 205.34 & 6080224 & 769006.31 & 3190271.00 & 48 & 176.36 & 6071124 & 769006.31 & 3192914.25 \\
\hline 24 & 201.87 & 6090124 & 766258.06 & 3192914.25 & 49 & 176.10 & 6082424 & 766258.06 & 3190271.00 \\
\hline 25 & 200.32 & 6071924 & 769006.31 & 3187627.50 & 50 & 175.83 & 6081224 & 766258.06 & 3192914.25 \\
\hline
\end{tabular}

the study area in Table $8 \mathrm{~b}$ is $492.17 \mu \mathrm{g} \mathrm{m}^{-3}$, hour $24: 00$, 28th August 2006 at the receptor coordinate of $\mathrm{X}=766258.06, \mathrm{Y}=3192914.25$. For the same location,
Table $8 \mathrm{~b}$ and Fig. 12c show that the highest annual maximum concentration of non-methane hydrocarbons is $45.639 \mu \mathrm{g} \mathrm{m}^{-3}$. 
Table 8c: ISCST3 output data modeling results for the 10th highest annual average concentrations of non-methane hydrocarbons

\begin{tabular}{llll}
\multicolumn{3}{c}{ hydrocarbons } & \\
\hline & & Location coordinate in UTM $(\mathrm{m})$ \\
Rank & $\left(\mu \mathrm{g} \mathrm{m}^{-3}\right)$ & X & Y \\
\hline 1ST & 45.639 & 766258.06 & 3192914.25 \\
2ND & 44.757 & 769006.31 & 3190271.00 \\
3RD & 31.182 & 771754.56 & 3187627.50 \\
4TH & 29.452 & 769006.31 & 3192914.25 \\
5TH & 27.076 & 771754.56 & 3190271.00 \\
6TH & 23.262 & 769006.31 & 3195557.75 \\
7TH & 23.102 & 755265.13 & 3208774.25 \\
8TH & 22.776 & 774502.75 & 3184984.25 \\
9TH & 21.799 & 752516.88 & 3211417.75 \\
10TH & 21.220 & 771754.56 & 3184984.25 \\
\hline
\end{tabular}

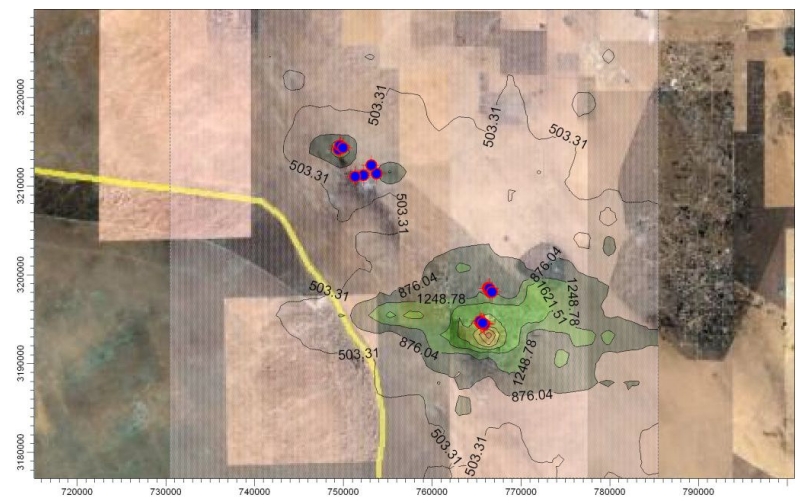

Fig. 12a: Isopleths plot for the maximum hourly average ground level concentrations of nonmethane hydrocarbons in $\mu \mathrm{g} \mathrm{m}^{-3}$

Methane emission: Table 9a-c show the modeling results for the 50 highest hourly, 50 highest daily and the 50 highest annual maximum ground level concentrations of methane, respectively calculated at the uniform grid receptors described previously. Isopleths plots (contours) were generated, as show in Fig. 13a-13c. These present the maximum hourly, daily and annual ground level concentration of methane in $\mu \mathrm{g} \mathrm{m}^{-3}$ calculated at the specified uniform grid receptors.

As shown in Table 9a the predicted maximum hourly average ground level concentration of methane in the study area is $221.02 \mu \mathrm{g} \mathrm{m}^{-3}$, hour 15:00, 25th August 2006 at the receptor coordinate of $\mathrm{X}=766258.06, \mathrm{Y}=3192914.25$.

The predicted maximum daily average ground level concentration of methane in the study area in Table $9 \mathrm{~b}$ is $31.075 \mu \mathrm{g} \mathrm{m}^{-3}$, hour 24:00, 25th August 2006 at the receptor coordinate of $X=766258.06$, $\mathrm{Y}=3192914.25$. For the same location, Table 9c and Fig. $13 \mathrm{c}$ show that the highest annual maximum concentration of methane is $2.764 \mu \mathrm{g} \mathrm{m}^{-1}$.

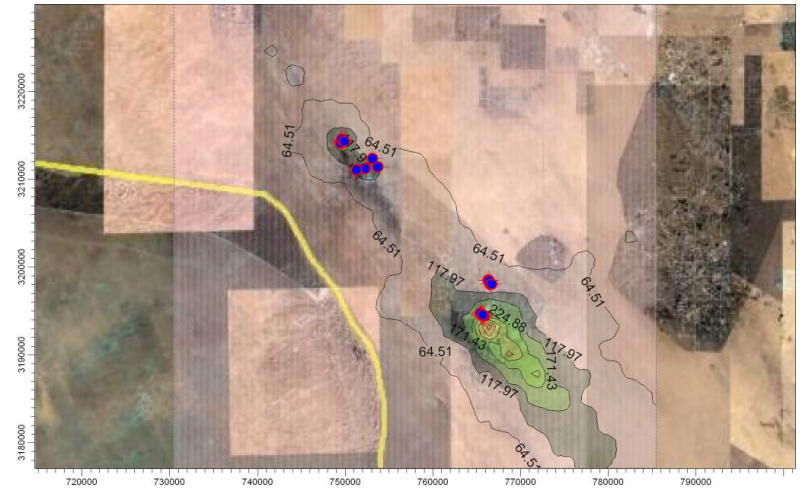

Fig. 12b: Isopleths plot for the maximum hourly average ground level concentrations of nonmethane hydrocarbons in $\mu \mathrm{g} \mathrm{m}^{-3}$

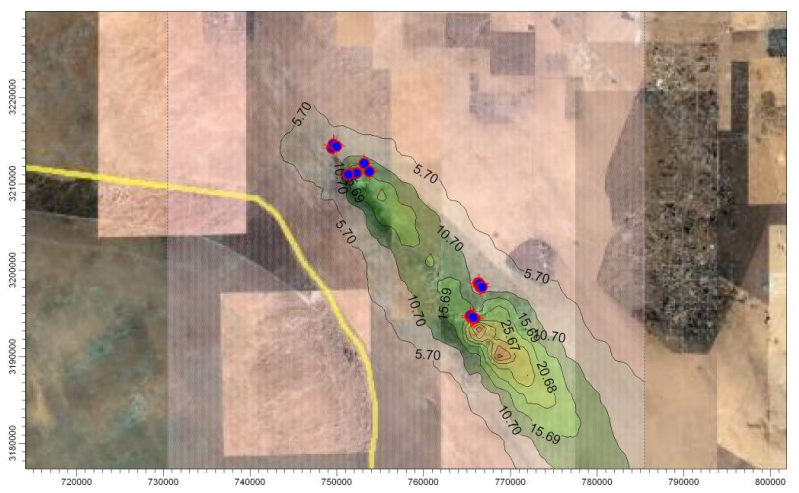

Fig. 12c: Isopleths plot for the maximum annual average ground level concentrations of nonmethane hydrocarbons in $\mu \mathrm{g} \mathrm{m}^{-3}$

The above data reflect the increase of emissions as a result of increase in flaring in August 2006 due to regular shut down of Shuaiba AGRP and CRU's of WK gathering centers. In addition to this complete shutdown of the two main GC's in WK Oilfields for survey, have contributed to the increase of flaring.

After the comparison between the simulated results for emission scenarios in the North, Southeast and West Kuwait Oilfields it can be concluded the following:

- $\quad$ NK Oilfields have generated a high ground level concentration of methane and non-methane hydrocarbons emissions than SEK and WK Oilfields. This is because of the unexpected problems in NK Oilfields. The amount of gas flared in these fluids as a percentage of production in January 2006, was about double that of the previous year 
Am. J. Environ. Sci., 4 (5): 420-438, 2008

Table 9a: ISCST3 output data modeling results for the 50 highest hourly average concentrations of methane

\begin{tabular}{|c|c|c|c|c|c|c|c|c|c|}
\hline \multirow[b]{2}{*}{ Rank } & \multirow{2}{*}{$\begin{array}{l}\text { CONC. } \\
\left(\mu \mathrm{g} \mathrm{m}^{-1}\right)\end{array}$} & \multirow[b]{2}{*}{ (YYMMDDHH) } & \multicolumn{2}{|c|}{ Location coordinate in UTM (m) } & \multirow[b]{2}{*}{ Rank } & \multirow{2}{*}{$\begin{array}{l}\text { CONC. } \\
\left(\mu \mathrm{g} \mathrm{m}^{-1}\right)\end{array}$} & \multirow[b]{2}{*}{ (YYMMDDHH) } & \multicolumn{2}{|c|}{ Location coordinate in UTM (m) } \\
\hline & & & $X$ & $\mathrm{Y}$ & & & & $\mathrm{X}$ & $\mathrm{Y}$ \\
\hline$\overline{1}$ & 221.02 & 6082515 & 766258.06 & 3192914.25 & 26 & 113.77 & $06082509)$ & 766258.06 & 3192914.25 \\
\hline 2 & 215.04 & 6082010 & 766258.06 & 3192914.25 & 27 & 112.97 & 06081611) & 766258.06 & 3192914.25 \\
\hline 3 & 210.59 & 6082508 & 766258.06 & 3192914.25 & 28 & 112.08 & $06102715)$ & 766258.06 & 3192914.25 \\
\hline 4 & 196.66 & 6080710 & 766258.06 & 3192914.25 & 29 & 111.79 & 06082808) & 769006.31 & 3195557.75 \\
\hline 5 & 168.83 & 6082810 & 766258.06 & 3192914.25 & 30 & 111.38 & 06081119) & 758013.31 & 3195557.75 \\
\hline 6 & 151.52 & 6080609 & 766258.06 & 3192914.25 & 31 & 111.30 & 06081006) & 769006.31 & 3192914.25 \\
\hline 7 & 150.89 & 6080812 & 766258.06 & 3192914.25 & 32 & 108.72 & 06081119) & 755265.13 & 3195557.75 \\
\hline 8 & 140.86 & 6081308 & 766258.06 & 3192914.25 & 33 & 108.65 & 06081118) & 763509.81 & 3192914.25 \\
\hline 9 & 138.19 & 6090209 & 766258.06 & 3192914.25 & 34 & 108.20 & $06082111)$ & 749768.63 & 3214061.00 \\
\hline 10 & 134.56 & 6080207 & 771754.56 & 3198201.00 & 35 & 108.01 & 06082212) & 766258.06 & 3192914.25 \\
\hline 11 & 134.38 & 6081517 & 763509.81 & 3192914.25 & 36 & 107.10 & 06092209) & 766258.06 & 3192914.25 \\
\hline 12 & 134.31 & 6071313 & 766258.06 & 3192914.25 & 37 & 106.43 & 06082207) & 769006.31 & 3192914.25 \\
\hline 13 & 133.99 & 6082812 & 749768.63 & 3214061.00 & 38 & 105.47 & 06092612) & 766258.06 & 3192914.25 \\
\hline 14 & 131.91 & 6082612 & 749768.63 & 3214061.00 & 39 & 103.23 & 06101111) & 766258.06 & 3192914.25 \\
\hline 15 & 131.88 & 6082811 & 749768.63 & 3214061.00 & 40 & 101.37 & 06081018) & 760761.56 & 3192914.25 \\
\hline 16 & 131.30 & 6080617 & 766258.06 & 3192914.25 & 41 & 101.35 & 06073116) & 766258.06 & 3192914.25 \\
\hline 17 & 130.63 & 6082414 & 766258.06 & 3192914.25 & 42 & 99.80 & 06070415) & 766258.06 & 3192914.25 \\
\hline 18 & 128.14 & 6082112 & 766258.06 & 3192914.25 & 43 & 99.44 & 06081408) & 769006.31 & 3190271.00 \\
\hline 19 & 126.85 & 6090710 & 766258.06 & 3195557.75 & 44 & 99.34 & 06082410) & 766258.06 & 3192914.25 \\
\hline 20 & 123.48 & 6082516 & 763509.81 & 3195557.75 & 45 & 98.97 & 06080507) & 769006.31 & 3195557.75 \\
\hline 21 & 122.33 & 6072212 & 766258.06 & 3192914.25 & 46 & 98.59 & 06081211) & 766258.06 & 3192914.25 \\
\hline 22 & 121.57 & 6070407 & 771754.56 & 3195557.75 & 47 & 96.99 & 06081115) & 766258.06 & 3192914.25 \\
\hline 23 & 117.76 & 6082416 & 766258.06 & 3192914.25 & 48 & 96.73 & 06070407) & 774502.75 & 3195557.75 \\
\hline 24 & 116.84 & 6080814 & 766258.06 & 3192914.25 & 49 & 96.68 & 06072612) & 766258.06 & 3192914.25 \\
\hline 25 & 116.02 & 6073108 & 769006.31 & 3195557.75 & 50 & 94.90 & 06091717) & 766258.06 & 3192914.25 \\
\hline
\end{tabular}

Table 9b: ISCST3 output data modeling results for the 50 highest daily average concentrations of methane

\begin{tabular}{|c|c|c|c|c|c|c|c|c|c|}
\hline \multirow[b]{2}{*}{ Rank } & \multirow[b]{2}{*}{$\begin{array}{l}\mathrm{CONC}_{-} \\
\left(\mu \mathrm{g} \mathrm{m}^{-1}\right)\end{array}$} & \multirow[b]{2}{*}{ (YYMMDDHH) } & \multicolumn{5}{|c|}{ Location coordinate in UTM (m) } & \multicolumn{2}{|c|}{ Location coordinate in UTM (m) } \\
\hline & & & $X$ & $\mathrm{Y}$ & Rank & $\begin{array}{l}\text { CONC. } \\
\left(\mu \mathrm{g} \mathrm{m}^{-1}\right)\end{array}$ & (YYMMDDHH) & $\mathrm{X}$ & $\mathrm{Y}$ \\
\hline 1 & 31.074 & 6082524 & 766258.06 & 3192914.25 & 26 & 12.561 & 6071924 & 769006.31 & 3187627.50 \\
\hline 2 & 29.548 & 6082424 & 766258.06 & 3192914.25 & 27 & 12.552 & 6072624 & 771754.56 & 3184984.25 \\
\hline 3 & 22.549 & 6080324 & 769006.31 & 3190271.00 & 28 & 12.457 & 6090124 & 766258.06 & 3192914.25 \\
\hline 4 & 22.408 & 6070824 & 769006.31 & 3190271.00 & 29 & 12.447 & 6091724 & 766258.06 & 3190271.00 \\
\hline 5 & 20.503 & 6080624 & 766258.06 & 3192914.25 & 30 & 12.443 & 6072824 & 771754.56 & 3187627.50 \\
\hline 6 & 19.284 & 6080324 & 771754.56 & 3187627.50 & 31 & 12.393 & 6081124 & 766258.06 & 3192914.25 \\
\hline 7 & 18.542 & 6072024 & 769006.31 & 3190271.00 & 32 & 12.103 & 6070724 & 769006.31 & 3190271.00 \\
\hline 8 & 18.127 & 6082824 & 749768.63 & 3214061.00 & 33 & 12.100 & 6072224 & 766258.06 & 3192914.25 \\
\hline 9 & 18.126 & 6092224 & 766258.06 & 3192914.25 & 34 & 12.053 & 6082024 & 766258.06 & 3192914.25 \\
\hline 10 & 17.270 & 6072724 & 771754.56 & 3187627.50 & 35 & 11.968 & 6080824 & 766258.06 & 3192914.25 \\
\hline 11 & 16.927 & 6091724 & 766258.06 & 3192914.25 & 36 & 11.896 & 6080124 & 769006.31 & 3190271.00 \\
\hline 12 & 16.142 & 6071224 & 769006.31 & 3192914.25 & 37 & 11.832 & 6090724 & 766258.06 & 3195557.75 \\
\hline 13 & 16.104 & 6080524 & 769006.31 & 3190271.00 & 38 & 11.818 & 6090424 & 769006.31 & 3190271.00 \\
\hline 14 & 15.844 & 6072724 & 769006.31 & 3190271.00 & 39 & 11.783 & 6080524 & 771754.56 & 3187627.50 \\
\hline 15 & 15.535 & 6071624 & 769006.31 & 3190271.00 & 40 & 11.728 & 6072024 & 771754.56 & 3190271.00 \\
\hline 16 & 15.143 & 6071824 & 769006.31 & 3190271.00 & 41 & 11.685 & 6070824 & 771754.56 & 3187627.50 \\
\hline 17 & 15.076 & 6072624 & 766258.06 & 3192914.25 & 42 & 11.504 & 6092324 & 766258.06 & 3192914.25 \\
\hline 18 & 14.686 & 6080324 & 752516.88 & 3211417.75 & 43 & 11.388 & 6070924 & 769006.31 & 3190271.00 \\
\hline 19 & 14.553 & 6072824 & 769006.31 & 3190271.00 & 44 & 11.371 & 6081024 & 769006.31 & 3192914.25 \\
\hline 20 & 13.805 & 6072724 & 774502.75 & 3184984.25 & 45 & 11.369 & 6050724 & 766258.06 & 3192914.25 \\
\hline 21 & 13.401 & 6080324 & 774502.75 & 3184984.25 & 46 & 11.340 & 6073124 & 769006.31 & 3195557.75 \\
\hline 22 & 13.384 & 6071024 & 771754.56 & 3190271.00 & 47 & 11.209 & 6082424 & 766258.06 & 3190271.00 \\
\hline 23 & 13.257 & 6082824 & 766258.06 & 3192914.25 & 48 & 11.087 & 6080424 & 769006.31 & 3190271.00 \\
\hline 24 & 13.246 & 6082524 & 749768.63 & 3214061.00 & 49 & 11.065 & 6081224 & 766258.06 & 3192914.25 \\
\hline 25 & 12.973 & 6080224 & 769006.31 & 3190271.00 & 50 & 11.050 & 6072724 & 777251.00 & 3182341.00 \\
\hline
\end{tabular}

- Methane and non-methane hydrocarbons are not the only green house gasses which result from flaring activities. The flaring of excess gas is the largest single source of atmospheric emissions arising from KOC operations. However, flaring produces carbon dioxide oxides of sulphur and nitrogen (NOx) and other chemical species that are produced due to incomplete combustion, such as carbon monoxide, aldehydes, ketones and other organic compounds known as VOCs (Volatile 
Am. J. Environ. Sci., 4 (5): 420-438, 2008

Table 9c: ISCST3 output data modeling results for the 10th highest annual average concentrations of methane

\begin{tabular}{llll}
\hline & \multicolumn{3}{l}{ Location coordinate in UTM $(\mathrm{m})$} \\
Rank & $\begin{array}{l}\text { CONC } \\
\left(\mu \mathrm{g} \mathrm{m}^{-3}\right)\end{array}$ & $\mathrm{X}$ & $\mathrm{Y}$ \\
\hline 1ST & 2.7643 & 766258.06 & 3192914.25 \\
2ND & 2.7639 & 769006.31 & 3190271.00 \\
3RD & 1.9585 & 771754.56 & 3187627.50 \\
4TH & 1.8554 & 769006.31 & 3192914.25 \\
5TH & 1.7187 & 771754.56 & 3190271.00 \\
6TH & 1.6407 & 755265.13 & 3208774.25 \\
7TH & 1.5455 & 752516.88 & 3211417.75 \\
8TH & 1.5096 & 769006.31 & 3195557.75 \\
9TH & 1.4454 & 774502.75 & 3184984.25 \\
10TH & 1.3404 & 758013.31 & 3206131.00 \\
\hline
\end{tabular}

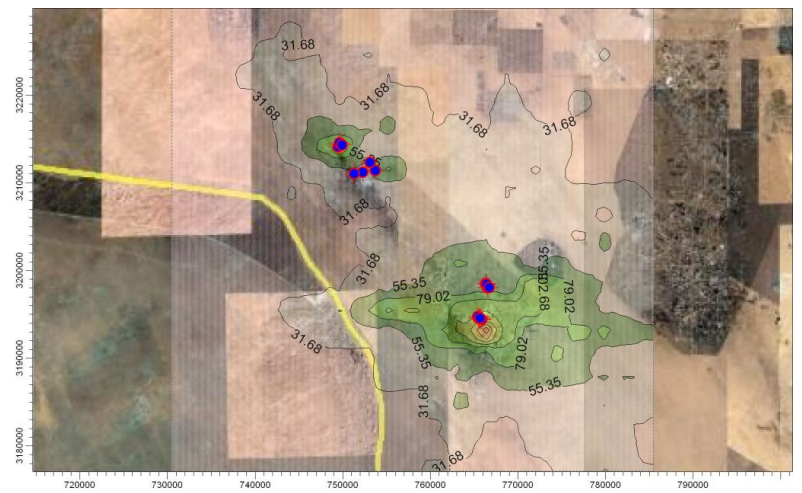

Fig. 13a: Isopleths plot for the maximum hourly average ground level concentrations of methane in $\mu \mathrm{g} \mathrm{m}^{-3}$

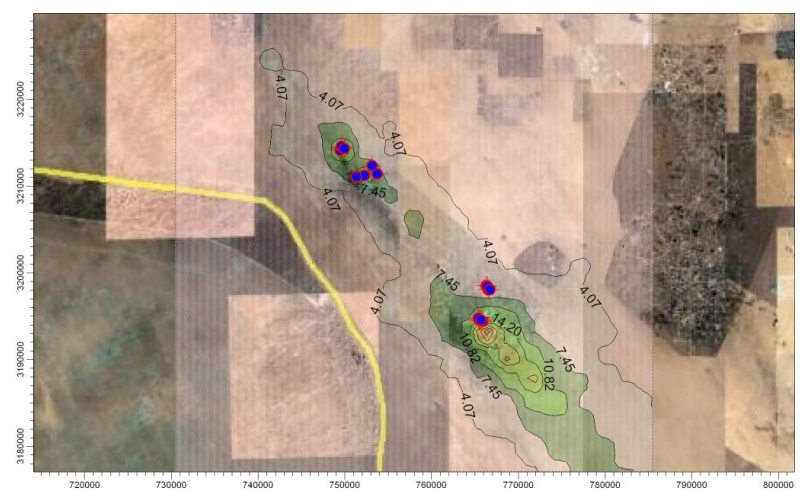

Fig. 13b: Isopleths plot for the maximum hourly average ground level concentrations of methane in $\mu \mathrm{g} \mathrm{m}^{-3}$

Organic Compounds). However the methane and non-methane hydrocarbons gases provide typical samples which can be used as an input for the ISCST3 model to investigate of the effects of emission from flaring in all Kuwait Oilfields

- There is a need for an emission inventory strategy for KOC to minimize the impact of methane and non-methane hydrocarbons released from flaring activities

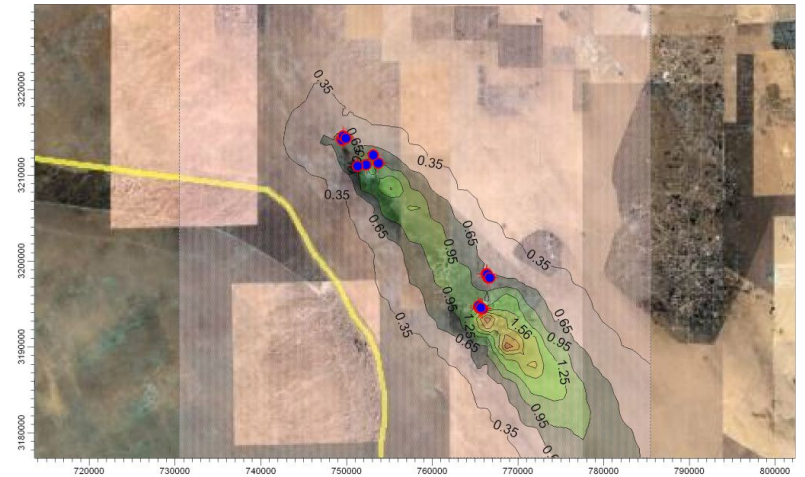

Fig. 13c: Isopleths plot for the maximum annual average ground level concentrations of methane in $\mu \mathrm{g} \mathrm{m}^{-3}$

\section{MODEL PERFORMANCE}

The performance of the model is evaluated based on the comparison of 50 highest daily measured and predicted concentrations of methane and non-methane hydrocarbons from KOC flaring at each monitoring station. The overall conclusion of this comparison is that the model predictions are in good agreement with the observed data with accuracy of $60-94 \%$ at the monitoring stations used by Kuwait EPA.

\section{CONCLUSION}

The simulation of real hourly air quality in the State of Kuwait for the year 2006, inserting the source emission data for that year into the ISCST3 software indicates that the levels of methane and non-methane hydrocarbons from flaring activities in NK Oilfields exceed the allowable daily ambient air standard set by Kuwait EPA.

The model prediction show that these green house gas levels are as much as 248.49 and $3099.8 \mu \mathrm{g} \mathrm{m}^{-3}$ above the accepted KAAQS for methane and nonmethane hydrocarbons, respectively.

Overall, the statistical comparison between the 50 highest daily measured and predicted concentrations at Kuwait existing monitoring sites shows that the model is in good agreement with the observed data.

This study can be extended to include other pollutants such as $\mathrm{NO}_{\mathrm{X}}, \mathrm{SO}_{2}, \mathrm{CO}, \mathrm{CO}_{2}$ and the organic components. Therefore, there is a need for a proper emission inventory strategy for $\mathrm{KOC}$ to minimize the impact of $\mathrm{NO}_{\mathrm{X}}, \mathrm{SO}_{2}, \mathrm{CO}, \mathrm{CO}_{2}$, methane and nonmethane hydrocarbons released from flaring activities. 


\section{ACKNOWLEDGMENT}

The researchers would like to thank Kuwait Oil Company for the field data used in this study and their permission to publish the results. Also, the authors would like to thank the Environmental Public Authority of Kuwait and Kuwait International Airport for the field data used in this study.

\section{REFERENCES}

1. Khaireyah, Kh. AL-Hamad and A.R. Khan, 2007. Total emissions from flaring in kuwait oilfields. ISSN 1553-345X@ 2007 Science Publications. Am. J. Environ. Sci., 4 (1): 31-38.

2. US Environmental Protection Agency, 1999. PCRAMMET User's Guide (Revised). EPA454/R-96-001. Office of Air Quality Planning and Standards, Research Triangle Park, North Carolina 27711.
3. US Environmental Protection Agency, 1995. User guide for the industrial source complex (ISC3) dispersion models. Volume I, User Instructions. EPA-450/B-95-003a. Research Triangle Park, N.C: Environmental Protection Agency. Office of Air Quality Planning and Standards, Emissions, Monitoring and Analysis Division.

4. US Environmental Protection Agency, 1992. User guide for the industrial source complex (ISC) dispersion models. EPA-450/4-92-008A. Research Triangle Park, N.C: Environmental Protection Agency. Office of Air Quality Planning and Standards.

5. Holzworth, G.C., 1972. Mixing heights, wind speeds and potential for urban air pollution throughout the contiguous United States. Office of Air Prog. pub. AP-101,USEPA, RTP, NC.

6. Hanna, S.R., 1969. The thickness of the planetary boundary layer. Atmos. Environ., 3: 519-536. 